\title{
Immune Checkpoint Blockade: The New Frontier in Cancer Treatment
}

\author{
Jeffrey M. Clarke ${ }^{1} \cdot$ Daniel J. George ${ }^{2} \cdot$ Stacey Lisi ${ }^{3} \cdot$ April K. S. Salama $^{4}$ \\ Published online: 13 February 2018 \\ (C) The Author(s) 2018. This article is an open access publication
}

\begin{abstract}
Immune checkpoint blockers have revolutionized cancer treatment in recent years. These agents are now approved for the treatment of several malignancies, including melanoma, squamous and non-squamous non-small cell lung cancer, renal cell carcinoma, urothelial carcinoma, and head and neck squamous cell carcinoma. Studies have demonstrated the significant impact of immunotherapy versus standard of care on patient outcomes, including durable response and extended survival. The use of immunotherapy-based combination therapy has been shown to further extend duration of response and survival. Immunotherapies function through modulation of the immune system, which can lead to immune-mediated adverse events (imAEs). These include a range of dermatologic, gastrointestinal, endocrine, and hepatic toxicities, as well as other less common inflammatory events. ImAEs are typically low grade and manageable when identified early and treated with appropriate measures. Identifying the right patient for the right therapy will become more important as new immunotherapies and immunotherapy-based combinations are approved and costs of cancer care continue to rise.
\end{abstract}

\section{Key Points}

Immunotherapies act differently from standard therapies: chemotherapy or targeted agents generally act directly on the tumor cells, whereas immunotherapies act on cancer cells indirectly by increasing activation of the immune system which ultimately leads to an anticancer immune response.

As cancer treatment continues to shift towards a more personalized approach, identifying predictive biomarkers will be essential to select patients who will benefit most from immunotherapy.

While single-agent immunotherapy is currently approved for several types of cancer, an area of important research consists in understanding how immunotherapy-based combination approaches may maximize clinical benefit.

Jeffrey M. Clarke

jeffrey.clarke@duke.edu

1 Division of Medical Oncology, Duke University School of Medicine, Duke Cancer Institute, DUMC 3198, Durham, NC 27710, USA

2 Division of Medical Oncology, Duke University School of Medicine, Duke Cancer Institute, Duke Box 103861, Durham, NC 27710, USA

3 Department of Pharmacy, Duke University Medical Center, Durham, NC 27710, USA

4 Division of Medical Oncology, Duke University School of Medicine, Duke Cancer Institute, Duke Box 3198, Durham, NC 27710, USA

\section{Introduction}

Immunotherapies such as immune checkpoint blockers (ICBs) are an established therapeutic approach to cancer treatment. It is important that physicians and other healthcare stakeholders who influence treatment decisions involving patient care, reimbursement, and drug access understand how immunotherapies differ from traditional chemotherapies and targeted agents, and the importance of proper patient selection. Knowledge of the efficacy of single-agent and combination therapies and their associated safety profiles will help guide informed decisions.

Multiple therapeutic approaches exist for the treatment of cancer, each with a distinct mechanism of action. Traditional cytotoxic chemotherapy agents interfere with cell proliferation and division by inhibiting molecular mechanisms common across normal and malignant cells, thus directly, but nonspecifically, destroying both healthy and cancerous cells. Targeted agents, such as some tyrosine kinase inhibitors (TKIs), are generally designed to destroy cancer cells directly by targeting specific genetic alterations present in those cells. Conversely, immunotherapies act on cancer cells indirectly through the regulation of the immune system [1]. Over time, tumor cells can develop mechanisms to evade immune system recognition $[2,3]$. One method for fighting malignancies is to increase activation of the immune system, which is required for successful destruction of cancer cells [2]. 
For decades, immunotherapies have been used as cancer treatments, including bacillus Calmette-Guérin in non-muscle invasive bladder cancer [4], high-dose interleukin-2 in metastatic renal cell carcinoma (RCC) and metastatic melanoma [5], and interferon $\alpha-2 b$ in adjuvant treatment of melanoma [6]. However, their efficacy has been limited by researchers' lack of understanding regarding the processes underlying immune regulation. Since 2010, additional immunotherapies have received U.S. Food and Drug Administration (FDA) approval, including sipuleucel-T [7], approved for treatment of asymptomatic or minimally symptomatic metastatic castration-resistant prostate cancer; talimogene laherparepvec (T-VEC) [8], approved for the treatment of unresectable melanoma, recurrent after initial surgery; tisagenlecleucel, approved for the treatment of pediatric and young adult patients with B-cell precursor acute lymphoblastic leukemia [9]; axicabtagene ciloleucel, approved for the treatment of adult patients with large B-cell lymphomas [10]; and ICBs including ipilimumab [11], nivolumab [12], pembrolizumab [13], atezolizumab [14], avelumab [15], and durvalumab [16], approved for a wide range of malignancies, including melanoma, non-small cell lung cancer (NSCLC), RCC, urothelial carcinoma (UC), head and neck squamous cell carcinoma (HNSCC), Hodgkin lymphoma, Merkel cell carcinoma, microsatellite instability-high (MSI-H) or mismatch repairdeficient (dMMR) cancer, hepatocellular carcinoma, and gastric or gastroesophageal junction adenocarcinoma (Table 1). Although not yet approved by the FDA, durvalumab was recently added to the National Comprehensive Cancer Network (NCCN) guidelines for NSCLC as consolidation therapy for patients with unresectable stage III NSCLC who have received two or more cycles of definitive concurrent chemoradiation [70, 71].

ICBs act on cancer cells indirectly by removing the "brakes" that serve to regulate $\mathrm{T}$ lymphocytes, the main cells responsible for triggering an anticancer immune response $[2$, 11-16]. ICBs are an established class of immunotherapy that target negative regulators of T-cell activation, specifically the immune checkpoints, cytotoxic T-lymphocyte-associated antigen-4 (CTLA-4), programmed cell death-1 (PD-1), and programmed cell death ligand-1 (PD-L1). Inhibition of these immune checkpoint molecules prevents the downregulation of immune cells, leading to enhanced T-cell activity, which ultimately results in increased antitumor immunity [2].

\section{Endpoints to Assess Clinical Outcomes Associated with ICBs}

Currently, overall survival (OS) is the gold standard clinical endpoint used to demonstrate direct clinical benefit for novel anticancer agents in support of regular FDA approval [72]. Improvements in median OS associated with ICBs versus other therapies have been reported in several cancer types (Table 2), including RCC treated with nivolumab versus the targeted agent everolimus [28], NSCLC treated with either pembrolizumab or atezolizumab versus the chemotherapeutic agent docetaxel [42, 57], and UC treated with pembrolizumab versus chemotherapy [46]. However, as novel agents extend patient survival times, it becomes increasingly difficult to conduct long clinical trials in order to measure OS $[75,76]$. Although the use of ICBs has improved survival in melanoma over standard chemotherapy, with some patients experiencing OS of 3 to 5 years [77, 78], when the follow-up is less than 1 year, median OS is usually not reached [22, 23, 39, 43]. Therefore, there is an interest in validating surrogate endpoints that can accurately predict survival benefit in clinical trials of immunotherapy and using these surrogate endpoints for drug approval [75].

The correlation between objective response rate (ORR), time to progression, disease-free survival, or progressionfree survival (PFS) and OS is poorly understood [76, 79]. Some studies investigating ICBs in NSCLC, RCC, HNSCC, and UC have demonstrated increased OS in the absence of a PFS benefit [27, 28, 31, 42, 47, 57], whereas other trials in melanoma and NSCLC have demonstrated increased OS, as well as ORR and PFS, compared with standard of care (Table 2) [23, 43].

Several ICBs have gained FDA accelerated approval based on ORR, including atezolizumab, nivolumab, durvalumab, and avelumab in previously treated patients with UC [12, 14-16]; pembrolizumab in previously treated patients with HNSCC [13]; combination nivolumab plus ipilimumab in melanoma [80]; and pembrolizumab in NSCLC, as monotherapy or in combination with chemotherapy [13, 41, 52]. PFS has been investigated in several meta-analyses as a surrogate endpoint for OS in metastatic melanoma [75, 81], and has served as the basis for FDA approval of first-line pembrolizumab in patients with NSCLC [13].

Generally, ICBs have been shown to significantly improve ORR when compared with standard therapies, for example in patients with melanoma [22, 23, 39], RCC [28], and NSCLC with high PD-L1 expression [43] (Table 2). ICBs have also been shown to prolong duration of response (DOR) when compared with standard therapies (Table 2) [22, 23, 25, 39, $42,43,46]$. The use of alternative endpoints as a surrogate for OS is an area of ongoing research, and further knowledge on this topic is likely to emerge in the near future.

\section{Immunotherapeutics and Patient Selection}

As the indications for approved ICBs expand, and new monotherapies and combination therapies come to market, the identification of biomarkers that predict benefit will be essential in selecting patients who will benefit most from immunotherapy. 


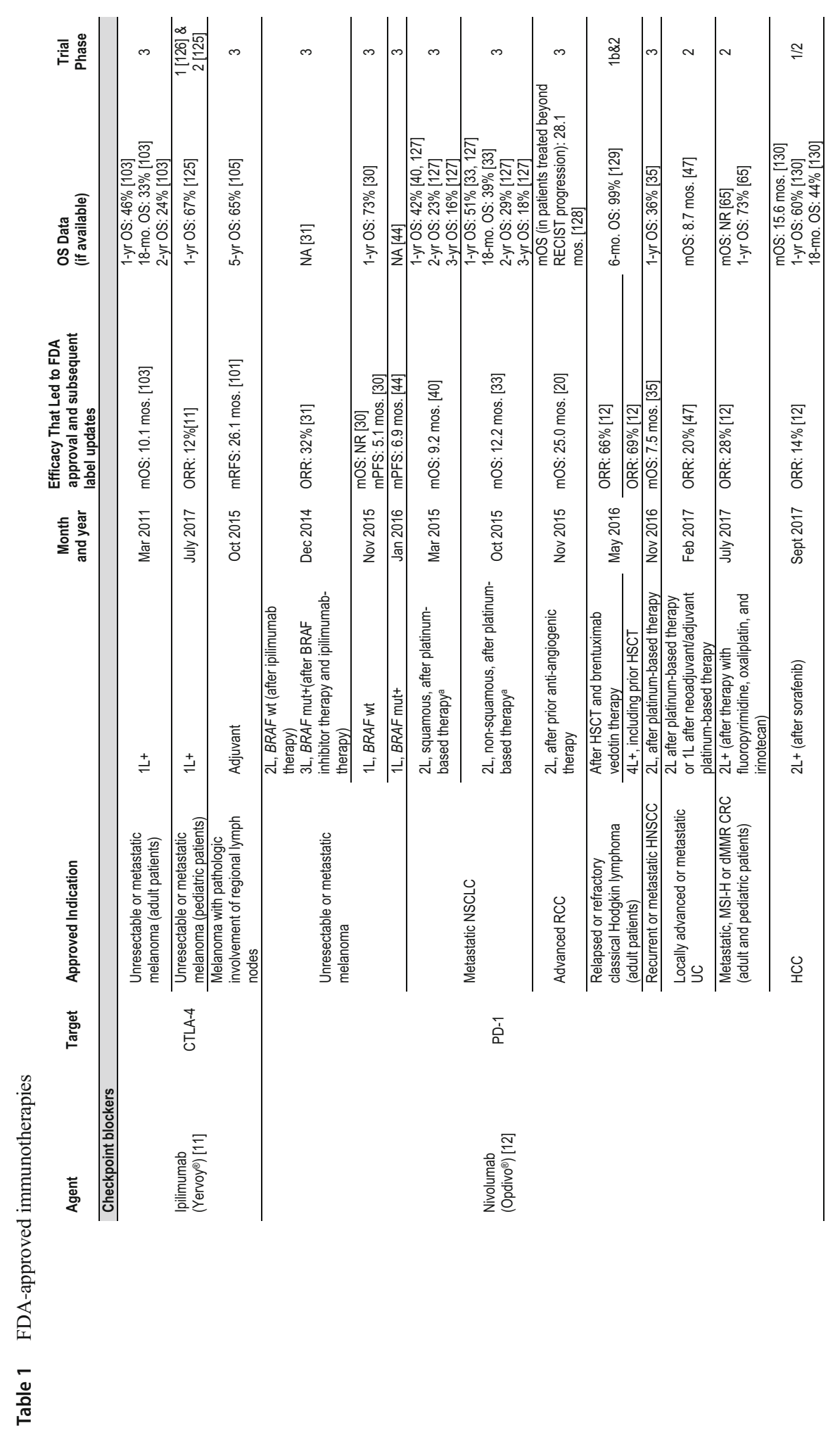




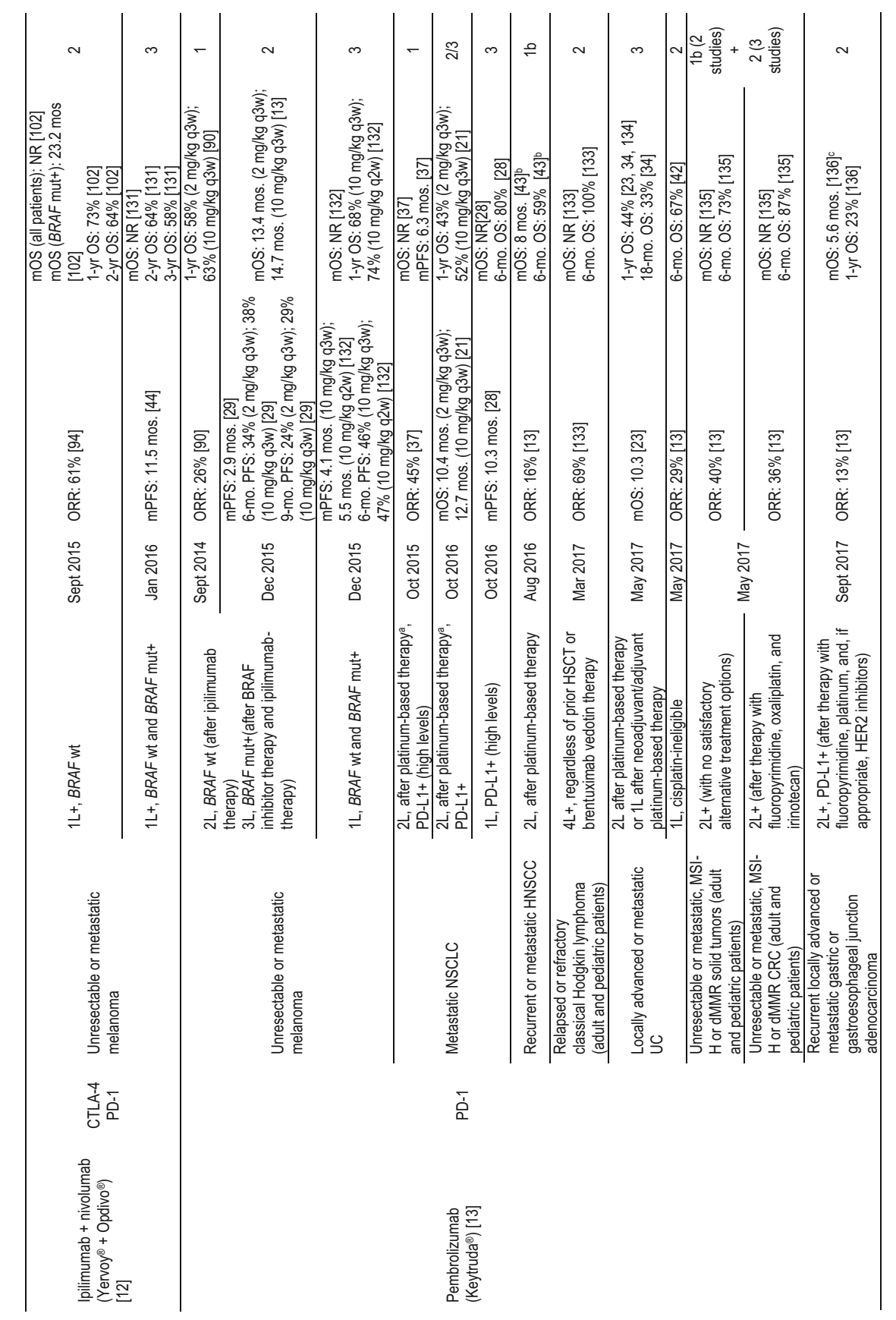

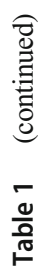




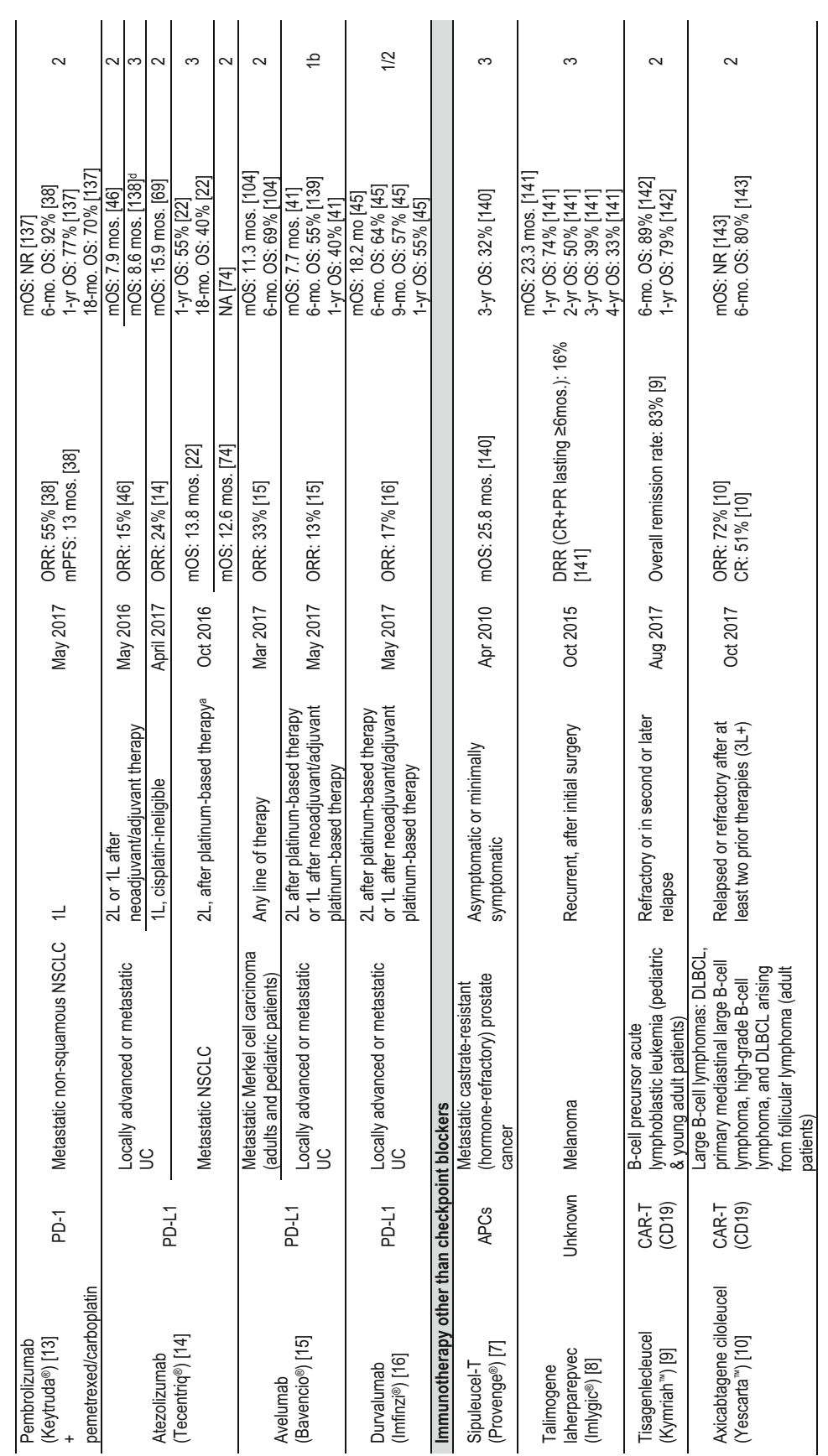

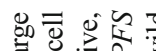

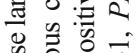

$\stackrel{\circ}{\circ}$

总言客要

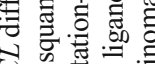

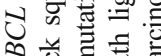

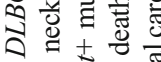

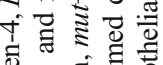

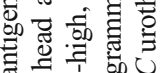

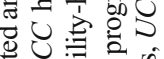

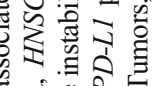

影司

항ㅎㅀ

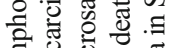

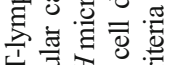

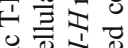

。

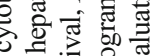

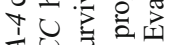

过记定品

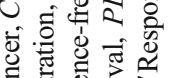

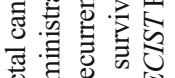

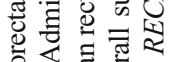

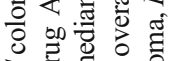

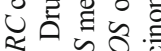

. 졸

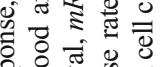

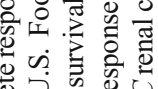

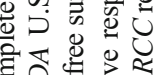

记

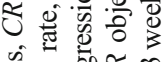

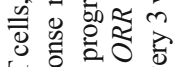

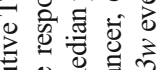

क्

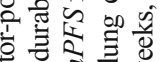

힐

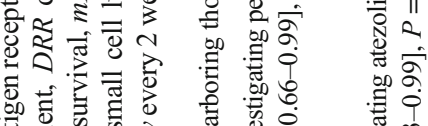

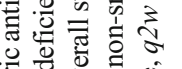

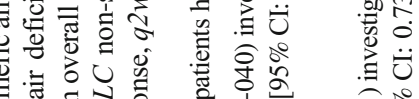

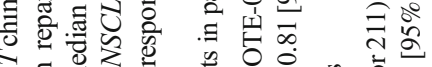

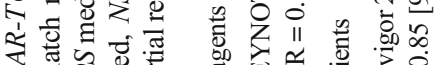

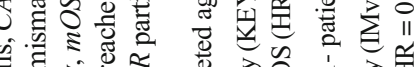

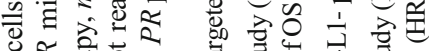

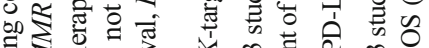

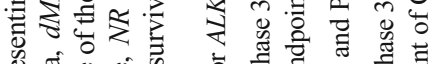

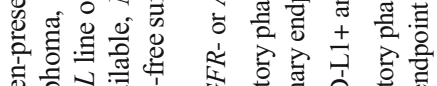

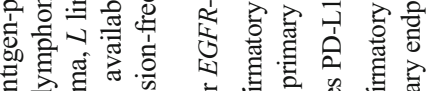

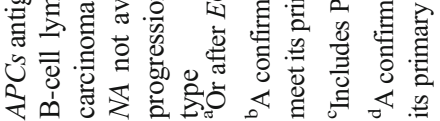


Table 2 Comparison of efficacy between checkpoint blockers as monotherapy and standard of care

\begin{tabular}{|c|c|c|c|c|c|c|c|c|c|c|c|c|}
\hline \multirow[b]{2}{*}{ Agent } & \multirow{2}{*}{$\begin{array}{l}\text { Trial name / } \\
\text { number }\end{array}$} & \multirow[b]{2}{*}{ Phase } & \multirow[b]{2}{*}{ Tumor Type } & \multicolumn{3}{|c|}{ Median OS, months } & \multicolumn{3}{|c|}{ ORR, \% } & \multicolumn{3}{|c|}{ Median DOR (range), months } \\
\hline & & & & ICB & Comparator & $\begin{array}{c}P \\
\text { value }\end{array}$ & ICB & Comparator & $\begin{array}{c}P \\
\text { value }\end{array}$ & ICB & Comparator & $\begin{array}{c}P \\
\text { value }\end{array}$ \\
\hline \multicolumn{13}{|l|}{ Anti-CTLA-4 } \\
\hline $\begin{array}{l}\text { Tremelimumab } \\
\text { (investigational) }\end{array}$ & $\begin{array}{l}\text { NCT00257205 } \\
{[147]}\end{array}$ & 3 & $\begin{array}{l}\text { Unresectable advanced melanoma } \\
\text { (1L) }\end{array}$ & 12.6 & $10.7^{\mathrm{a}}$ & 0.127 & 11 & $10^{a}$ & 0.618 & 35.8 & $13.7^{a}$ & 0.0011 \\
\hline \multicolumn{13}{|l|}{ Anti-PD-1 } \\
\hline \multirow{6}{*}{$\begin{array}{l}\text { Nivolumab } \\
\text { (FDA-approved) }\end{array}$} & \begin{tabular}{|l} 
CheckMate 037 \\
[31] \\
NCT01721746 \\
\end{tabular} & 3 & $\begin{array}{l}\text { Unresectable advanced or metastatic } \\
\text { melanoma }(2 \mathrm{~L}+)\end{array}$ & NA & NA & NA & 32 & $11^{b}$ & NA & $\begin{array}{c}\mathrm{NR} \\
(1.4+-10.0+)\end{array}$ & $\begin{array}{c}3.5^{b} \\
(1.3+-3.5)\end{array}$ & NA \\
\hline & $\begin{array}{l}\text { CheckMate } 066 \\
\text { [30] } \\
\text { NCT01721772 } \\
\end{array}$ & 3 & $\begin{array}{l}\text { Unresectable advanced or metastatic } \\
\text { melanoma, BRAF wt (1L) }\end{array}$ & NR & $10.8^{c}$ & $<0.001$ & 40 & $14 c$ & $<0.001$ & NR & $6.0(3 \mathrm{NR})^{\mathrm{c}}$ & NA \\
\hline & $\begin{array}{l}\text { CheckMate } 017 \\
\text { [40] } \\
\text { NCT01642004 } \\
\end{array}$ & 3 & Advanced squamous NSCLC (2L) & 9.2 & $6.0^{\mathrm{d}}$ & $<0.001$ & 20 & $9^{d}$ & 0.008 & $\begin{array}{c}\mathrm{NR} \\
(2.9-20.5+)\end{array}$ & $\begin{array}{c}8.4^{d} \\
(1.4+-15.2+)\end{array}$ & NA \\
\hline & $\begin{array}{l}\text { CheckMate } 057 \\
\text { [33] } \\
\text { NCT01673867 }\end{array}$ & 3 & Advanced non-squamous NSCLC (2L) & 12.2 & $9.4^{d}$ & 0.002 & 19 & $12^{\mathrm{d}}$ & 0.02 & $\begin{array}{c}17.2 \\
(1.8-22.6+)\end{array}$ & $\begin{array}{c}5.6^{d} \\
(1.2+-15.2+)\end{array}$ & NA \\
\hline & $\begin{array}{l}\text { CheckMate } 025 \\
{[20]} \\
\text { NCT01668784 }\end{array}$ & 3 & $\begin{array}{l}\text { Advanced or metastatic clear-cell RCC } \\
(2 \mathrm{~L}+)\end{array}$ & 25.0 & $19.6^{\mathrm{e}}$ & 0.002 & 25 & $5^{e}$ & $<0.001$ & $\begin{array}{c}12.0 \\
(0-27.6)\end{array}$ & $\begin{array}{c}12.0 \mathrm{e} \\
(0-22.2)\end{array}$ & NA \\
\hline & $\begin{array}{l}\text { CheckMate } 141 \\
\text { [35] } \\
\text { NCT02105636 } \\
\end{array}$ & 3 & $\begin{array}{l}\text { Platinum-refractory, recurrent HNSCC } \\
(2 \mathrm{~L}+)\end{array}$ & 7.5 & $5.1^{1 f}$ & 0.01 & 13 & $6^{f}$ & NA & NA & NA & NA \\
\hline \multirow{4}{*}{$\begin{array}{l}\text { Pembrolizumab } \\
\text { (FDA-approved) }\end{array}$} & $\begin{array}{l}\text { KEYNOTE-002 } \\
{[29]} \\
\text { NCT01704287 } \\
\end{array}$ & 2 & $\begin{array}{l}\text { Unresectable advanced or metastatic } \\
\text { melanoma (ipilimumab-refractory, } 2 \mathrm{~L}+\text { ) }\end{array}$ & NA & NA & NA & 239 & $4^{\mathrm{h}}$ & $<0.0001$ & $\begin{array}{c}\mathrm{NRg} \\
(5.8-\mathrm{NR})\end{array}$ & $\begin{array}{c}8.5^{\mathrm{h}} \\
(2.8-9.5)\end{array}$ & NA \\
\hline & $\begin{array}{l}\text { KEYNOTE-010 } \\
\text { [21] } \\
\text { NCT01905657 } \\
\end{array}$ & $2 / 3$ & Advanced, PD-L1+ NSCLC (2L+) & $\begin{array}{l}10.4 \mathrm{i} \\
12.7^{\mathrm{j}}\end{array}$ & $8.5^{\mathrm{d}}$ & $\begin{array}{l}0.0008 i \\
<0.0001 j\end{array}$ & 189 & $9 d$ & $\begin{array}{l}0005^{i} \\
0002\end{array}$ & $\begin{array}{c}\mathrm{NRg}^{\mathrm{g}} \\
(4.2-12.5)^{\mathrm{g}}\end{array}$ & $\begin{array}{c}6.0^{\mathrm{d}} \\
(2.7-6.1)\end{array}$ & NA \\
\hline & $\begin{array}{l}\text { KEYNOTE-024 } \\
{[28]} \\
\text { NCT02142738 } \\
\end{array}$ & 3 & $\begin{array}{l}\text { Metastatic, PD-L1+ (high levels) } \\
\text { NSCLC (1L) }\end{array}$ & $N R^{k, l}$ & NRj,k,l,m & $N A^{k, I}$ & 45 & $28^{m}$ & NA & $\begin{array}{c}\mathrm{NR} \\
(1.9+-14.5+)\end{array}$ & $\begin{array}{c}6.3^{m} \\
(2.1+-12.6+) \\
\end{array}$ & NA \\
\hline & $\begin{array}{l}\text { KEYNOTE-045 } \\
{[23,34,134]} \\
\text { NCT02256436 } \\
\end{array}$ & 3 & $\begin{array}{l}\text { Advanced UC (platinum-refractory, } \\
2 / 3 L \text { ) }\end{array}$ & 10.3 & $7.4^{n}$ & 0.0003 & 21 & $11^{n}$ & 0.001 & $\begin{array}{c}\mathrm{NR} \\
(1.6+-24.6+)\end{array}$ & $\begin{array}{c}4.4^{\mathrm{n}} \\
\left(1.4^{+}-24.0+\right)\end{array}$ & NA \\
\hline \multicolumn{13}{|l|}{ Anti-PD-L1 } \\
\hline \multirow[t]{3}{*}{$\begin{array}{l}\text { Atezolizumab } \\
\text { (FDA-approved) }\end{array}$} & $\begin{array}{l}\text { POPLAR [74] } \\
\text { NCT01903993 }\end{array}$ & 2 & $\begin{array}{l}\text { Locally advanced or metastatic } \\
\text { NSCLC (platinum-refractory, } 2 / 3 \mathrm{~L} \text { ) }\end{array}$ & 12.6 & $9.7^{\mathrm{d}}$ & 0.040 & 15 & $15^{d}$ & NA & $\begin{array}{c}14.3 \\
(11.6-\mathrm{NE})\end{array}$ & $\begin{array}{c}7.2^{\mathrm{d}} \\
(5.6-12.5)\end{array}$ & .034 \\
\hline & $\begin{array}{l}\text { OAK [22] } \\
\text { NCT02008227 }\end{array}$ & 3 & $\begin{array}{l}\text { Locally advanced or metastatic } \\
\text { NSCLC (platinum-refractory, } 2 / 3 \mathrm{~L} \text { ) }\end{array}$ & 13.8 & $9.6^{d}$ & 0.0003 & 14 & $13^{d}$ & NA & $\begin{array}{c}16.3 \\
(10.0-\mathrm{NE})\end{array}$ & $\begin{array}{c}6.2^{\mathrm{d}} \\
(4.9-7.6)\end{array}$ & $<.0001$ \\
\hline & $\begin{array}{l}\text { IMvigor } 211[138] \\
\text { NCT02302807 }\end{array}$ & 3 & $\begin{array}{l}\text { Locally advanced or metastatic } \mathrm{UC} \\
\text { (platinum-refractory, } 2 \mathrm{~L}+\text { ) }\end{array}$ & 8.6 & $8.0^{n}$ & 0.038 & 13 & $13^{n}$ & NA & $\begin{array}{c}21.7 \\
(13.0-21.7)\end{array}$ & $\begin{array}{c}7.4^{\mathrm{n}} \\
(6.1-10.3)\end{array}$ & NA \\
\hline
\end{tabular}

$A P C s$ antigen-presenting cells, CTLA-4 cytotoxic T-lymphocyte-associated antigen-4, DOR duration of response, FDA U.S. Food and Drug Administration, $H N S C C$ head and neck squamous cell carcinoma, ICB immune checkpoint blocker, $L$ line of therapy, $N A$ not available, $N E$ not estimable/not evaluable, $N R$ not reached, $N S C L C$ non-small cell lung cancer, $O R R$ objective response rate, $O S$ overall survival, $P D-1$ programmed cell death-1, $P D-L 1$ programmed death ligand-1, $R C C$ renal cell carcinoma, $U C$ urothelial carcinoma

${ }^{a}$ Comparator was investigator's choice single-agent chemotherapy: dacarbazine or temozolomide

${ }^{\mathrm{b}}$ Comparator was investigator's choice chemotherapy: dacarbazine or carboplatin/paclitaxel

${ }^{\mathrm{c}}$ Comparator was dacarbazine

${ }^{\mathrm{d}}$ Comparator was docetaxel

${ }^{\mathrm{e}}$ Comparator was everolimus

${ }^{\mathrm{f}}$ Comparator was investigator's choice single-agent chemotherapy: methotrexate, docetaxel, or cetuximab

${ }^{\mathrm{g}}$ Includes both 2-mg/kg and 10-mg/kg pembrolizumab treatment groups

${ }^{\mathrm{h}}$ Comparator was investigator's choice chemotherapy: carboplatin/paclitaxel, paclitaxel, carboplatin, dacarbazine, or oral temozolomide

i $2 \mathrm{mg} / \mathrm{kg}$ pembrolizumab

${ }^{\mathrm{j}} 10 \mathrm{mg} / \mathrm{kg}$ pembrolizumab

${ }^{\mathrm{k}}$ OS at 6 months was $80 \%$ for pembrolizumab and $72 \%$ for chemotherapy $(P=0.005)$

${ }^{1}$ At a median follow-up of 19.1 months, mOS was not reached with pembrolizumab and 14.5 months with chemotherapy $(P=0.003)$ [74]

${ }^{\mathrm{m}}$ Comparator was investigator's choice chemotherapy: carboplatin/pemetrexed, cisplatin/pemetrexed, carboplatin/gemcitabine, cisplatin/gemcitabine, or carboplatin/paclitaxel

${ }^{\mathrm{n}}$ Comparator was investigator's choice single-agent chemotherapy: paclitaxel, docetaxel, or vinflunine 
The immunologic profile of the tumor can be taken into consideration when selecting appropriate patients. The level of PD-L1 expression within tumor cells and/or immune cells is associated with higher ORR or longer OS following treatment with PD-1/PD-L1 blockers in NSCLC and UC, pembrolizumab in HNSCC, and nivolumab in melanoma [23, 24, 27, 32, 41, 42, 44, 49, 54, 60, 62]. However, some patients with low or no levels of PD-L1 expression also respond to ICBs [27], indicating that PD-L1 expression is enriched for responders, but the absence of expression is not an absolute indicator of lack of benefit. Finally, some clinical trials in NSCLC have shown no strong correlation between outcome and baseline PD-L1 status [25].

To identify patients who may receive the most benefit from ICBs, a series of FDA-approved diagnostic assays has been developed to measure the level of PD-L1 expression in tumor and/or immune cells. These assays include one mandatory companion diagnostic with pembrolizumab monotherapy for patients with NSCLC or gastric/gastroesophageal junction adenocarcinoma (PD-L1 IHC 22C3 pharmDX, Dako) [82], and three complementary (optional) diagnostics: PD-L1 IHC 28-8 pharmDX (Dako) for nivolumab (non-squamous NSCLC, HNSCC, and UC) or nivolumab/ipilimumab combination (melanoma) [83], VENTANA PD-L1 SP142 assay for atezolizumab (UC and NSCLC) [84], and VENTANA PD-L1 SP-263 for durvalumab (UC) [85]. Therefore, PD-L1 testing should be used for patient selection only when planning to administer pembrolizumab in patients with NSCLC (except when pembrolizumab is used in first line $[1 \mathrm{~L}]$ in combination with chemotherapy) or gastric/gastroesophageal junction adenocarcinoma [13]. Despite the development of FDA-approved assays for PD-L1 testing, some clinics use laboratorydeveloped tests, which can be less costly but can also increase the amount of testing variability [86]. Variability in PD-L1 testing can arise because of the type (tumor cells, immune cells, or a combination) and percentage cutoffs used for positivity, archival versus fresh tissue, primary versus metastatic biopsies, diversity of antibodies utilized, and tumor heterogeneity [86, 87]. Several comparative studies across different PD-L1 assays have been conducted, including collaborative studies between industry and academic institutions [88-91]. The outcomes of these studies have varied, with two studies showing concordance among assays $[88,90]$, one study showing equivalence for most assays [91], and one study revealing differences across all of the assays that do not support interchangeability [89]. Based on these preliminary findings, the PD-L1 assays that are currently available are not considered interchangeable.

The presence of tumors that harbor mutations in specific genes can influence therapy decisions. For example, the use of epidermal growth factor receptor (EGFR) TKIs is standard of care in patients with EGFR-mutation-positive NSCLC [92-94], and studies suggest that this population may not derive benefit from immunotherapy versus EGFR TKIs [95] or chemotherapy [96]. Therefore, the clinical benefit from monotherapy with anti-PD-1/PD-L1 antibodies remains suboptimal in EGFR-mutation-positive NSCLC, and novel combination and therapeutic approaches are needed [96]. The approval of anti-PD-1 therapy for the treatment of adult and pediatric patients with MSI-H or dMMR solid tumors (pembrolizumab) or colorectal cancer (pembrolizumab and nivolumab) that has progressed, underscores the importance of considering other biomarkers that are not specific to the immune checkpoint pathway when making ICB therapy decisions [13]. Patients with MMR deficiency are associated with a higher mutational burden and tumor neoantigen load than MMR-proficient patients, and these features could be driving clinical benefit of ICBs [33, 97, 98]. In fact, tumor mutational burden, known to enhance neoantigen formation, has been shown to be associated with increased response to ICBs, and in some cases improved OS as well, across tumor types such as melanoma [99, 100], NSCLC [101], and UC $[54,56,102]$. Baseline gene expression profiling has also been correlated with response to ICBs; specifically, interferon gamma (IFN $\gamma$ ) signature, which is indicative of an inflammatory tumor microenvironment, is associated with responsiveness to ICBs in several tumor types, including melanoma [103], UC [32, 54, 104, 105], NSCLC [58, 106], HNSCC [103], and gastric cancer [103].

Patients with autoimmune diseases raise concerns about the risk of immune-mediated toxicity associated with immunotherapy and are often excluded from clinical trials. However, as the use of immunotherapy continues to expand into a broader, real-world population, patients with preexisting autoimmune disorders or immune-mediated adverse events (imAEs) from prior immunotherapy are being considered [107, 108]. In one study, the use of the PD-1 blockers pembrolizumab or nivolumab in 119 patients with advanced melanoma and preexisting autoimmune disorders and/or imAEs from prior ipilimumab monotherapy resulted in an ORR of $37 \%$, although approximately $10 \%$ of patients discontinued treatment because of imAEs [108].

Other factors that may influence immunotherapy treatment decisions include performance status, comorbidities that are incompatible with imAEs associated with these agents, and the presence of brain metastases. Although the majority of the clinical trials testing ICBs exclude patients with active brain metastases, pembrolizumab was administered to 36 patients with melanoma or NSCLC and untreated or progressive brain metastases in an investigator-initiated phase 2 trial. Relevant reduction in brain metastases was observed in $28 \%$ of patients, warranting further investigation of ICBs in this patient population [109]. In the phase 2 CheckMate 204 study, the combination of nivolumab and ipilimumab was administered to 75 patients with advanced melanoma and untreated brain metastases, and provided an intracranial ORR of $55 \%$ and an extracranial ORR of $49 \%$ [110]. 
Modern oncologic therapies are increasingly reliant on biomarkers within the tumor microenvironment. Personalized cancer care in the immediate future will have even greater dependence on predictive biomarkers for optimizing therapeutic options for patients. Therefore, the development and validation of novel biomarkers that identify patients who will benefit from anticancer treatments is critical. Biomarker assays are urgently needed, including assays for circulating biomarkers, which optimize test feasibility, convenience, and accuracy, and are non-invasive, preserving patient safety.

\section{Pseudoprogression with ICBs}

Measuring clinical outcomes associated with immunotherapies comes with a distinct set of challenges not observed with standard therapies. In some cases, the time required to establish an effective immune response may be delayed compared with standard therapies because of atypical responses reported with immunotherapies that are not observed with targeted agents or chemotherapy [111]. Pseudoprogression, also called tumor flare, is a distinct immune-related pattern of response caused by the infiltration of immune cells to the tumor site that can manifest in the form of an apparent increase in tumor size, the development of new lesions, or a mixed response such as progression and regression of different tumors in the same patient $[112,113]$. The development of granulomatous changes in the lymph nodes resembling progression have also been described during immunotherapy treatment [114]. In studies investigating immunotherapies in patients with cancer, the prevalence of pseudoprogression can vary based on tumor type; for example, it has been reported to be $7 \%$ to $10 \%$ in melanoma [23, 113, 115], 5\% to $7 \%$ in NSCLC [25, 27], 7\% in UC [54], and $0 \%$ to $2 \%$ in HNSCC $[44,116]$.

Following the standard RECIST (Response Evaluation Criteria In Solid Tumors) v1.1 criteria [117], findings of pseudoprogression can be initially interpreted as disease progression and may lead to discontinuation of treatment before the potential clinical benefit of immunotherapy is fully realized $[111,112]$. Studies have demonstrated that after initial apparent disease progression, some patients derive clinical benefit from continued administration of immunotherapy [22, 38, 57, 111, 118-121]. In a phase 3 study (CheckMate $025), 69 \%$ of patients with metastatic RCC treated with nivolumab beyond first progression subsequently demonstrated tumor reduction in target lesions, and almost half (48\%) had a 30\% reduction in tumor burden from baseline [111]. In another phase 3 study (CheckMate 037) investigating nivolumab in patients with advanced melanoma, $31 \%$ received treatment beyond progression, and $27 \%$ of these had a greater than $30 \%$ reduction in target lesions [22]. Similar findings were observed in 62 patients with recurrent or metastatic HNSCC treated with nivolumab beyond progression in the phase 3 CheckMate 141 , with $24 \%$ of these patients experiencing tumor reduction [118], and in 137 patients with advanced or metastatic UC treated with atezolizumab beyond progression in the phase 2 IMvigor 210, with 33\% experiencing tumor reduction [120]. In patients from IMvigor 210, prolonged survival was observed in subgroups of patients with favorable baseline prognostic characteristics (Eastern Cooperative Oncology Group performance status 0, lymph node-only disease, or no visceral metastases) [120]. Because of the unique responses observed with these agents, immunerelated response criteria (irRC) have been developed to serve as a guide for the evaluation of antitumor responses with immunotherapies [113]. Based on survival analysis from patients with melanoma treated with pembrolizumab in the KEYNOTE 001 trial, the benefit of immunotherapy was underestimated in approximately $15 \%$ of patients when assessed by conventional RECIST v1.1 versus irRC [115]. Currently, irRC is often used in clinical trials of immunotherapy as a secondary approach for measuring responses, whereas standard RECIST is more prevalent in clinical practice.

According to the authors' personal experience, when treating long-term survivors who are experiencing a durable response from immunotherapy, it may be possible to incorporate treatment breaks followed by treatment rechallenge in cases of subsequent disease progression, although treatment breaks are not indicated in the label. In the KEYNOTE-006 study, 104 ipilimumab-naïve patients with advanced melanoma completed 2 years of pembrolizumab treatment: of these patients, $23 \%, 65 \%$, and $12 \%$ had complete response (CR), partial response (PR), and stable disease (SD), respectively, at the time of completion of pembrolizumab treatment [122]. After a median follow-up of nearly 3 years, most (91\%) of these 104 patients were progression-free, with ongoing CR, PR, and SD experienced by $22 \%, 62 \%$, and $10 \%$ of patients, respectively [122]. Understanding the role of treatment breaks with immunotherapy is an area in need of further investigation.

\section{Immunotherapy-Based Combination Approaches}

Combination regimens, including two immunotherapies administered together or immunotherapy combined with either chemotherapy or targeted agents, may increase the number of patients with durable response or longer survival (Table 3). The PD-1/PD-L1 and CTLA-4 blockers target different pathways involved in immune regulation, and the combination of these agents enhances tumor response compared with monotherapy [141]. The initial approval of ipilimumab/nivolumab combination therapy for first-line treatment of melanoma was based on the high ORR reported with this combination versus single-agent ipilimumab in the CheckMate 069 study 
(Table 3) [35], and was further supported by the phase 3 CheckMate 067 study, which showed significant improvements in median PFS $[12,24]$. The accelerated approval of pembrolizumab plus chemotherapy (pemetrexed/carboplatin) for first-line treatment of non-squamous NSCLC was based on the high ORR reported with this combination versus pemetrexed/carboplatin alone in the KEYNOTE-021 trial (Table 3) [52]. Additional immunotherapy-based combination therapies are being tested in phase 3 studies (Table 4), and for some of these combination approaches, preliminary data are available (Table 3 ).

The concurrent use of immunotherapies in combination regimens, along with the supportive care required to manage increased toxicity, may contribute to the overall healthcare costs associated with these agents. Based on current labeling for the treatment of melanoma patients, ipilimumab and nivolumab are administered together only for the initial four doses; nivolumab is then given as monotherapy [12]. Alternative dosing regimens for ICBs used in combination are currently under investigation, with the goal of improving the safety profile while maximizing clinical benefit $[125,142$, 143].

\section{Adverse Events Associated with ICBs}

By enhancing immune system function, ICBs can lead to adverse events (AEs) distinct from chemotherapy [144, 145], which include a range of dermatologic, gastrointestinal (GI), endocrine, and hepatic toxicities, as well as other less common inflammatory events [146]. Though imAE onset is variable, most occur during the initial months of therapy [11-16]. Whereas imAEs of any grade can occur in up to $90 \%$ of patients treated with ICBs as monotherapy $[17,20$, $24,36,42,43,54,56,59,62]$, the incidence of grade $\geq 3$ imAEs can range from $1 \%$ to $10 \%$ with anti-PD-1/PD-L1 monotherapy $[24,43,54,56,59,62]$ and from $15 \%$ to $42 \%$ with anti-CTLA-4 monotherapy $[17,20,24,36]$. Combination therapy with anti-CTLA-4 and anti-PD-1 antibodies is associated with a $40 \%$ to $45 \%$ incidence of grade $\geq 3$ imAEs $[24,36]$. Although infrequent, life-threatening imAEs can occur with ICBs [11-16].

Because severe imAEs can lead to treatment discontinuation, careful monitoring and prompt management are important to ensure patients continue to receive beneficial immunotherapy. Unlike chemotherapy, which can only be tolerated for shorter durations (e.g., 6 cycles), immunotherapy agents can be administered for up to 2 or 3 years in some cases [21, 147, 148]. Although recent analyses on cumulative toxicity associated with ICBs after long-term therapy are needed, an analysis conducted in 306 patients with advanced solid tumors treated for up to 22 months with nivolumab monotherapy in a phase 1 study showed no cumulative toxicity after a minimum of 14 months of follow-up [148]. In a pooled safety analysis of 282 patients with advanced melanoma who were treated with nivolumab monotherapy in two phase 3 and two phase 1 studies and who experienced new treatment-related imAEs, $85 \%$ did so within the first 16 weeks of treatment [149]. Based on a long-term safety analysis conducted in 95 patients with metastatic UC treated with atezolizumab in a phase 1a trial, most treatment-related AEs occurred within the first year after treatment initiation, with a $50 \%$ reduction in the incidence of these AEs during the second year [150]. Therefore, patient monitoring remains important with longterm therapy due to the rare occurrence of late-onset imAEs.

Guidelines for the management of imAEs have been proposed in expert reviews $[144,145,151,152]$ but are also available within the prescribing information for each agent and in brochures that can be downloaded from the manufacturers' websites [11-16, 153-157]. Most moderate and severe immune-mediated toxicities can be managed effectively with corticosteroids and can be resolved within 6 to 12 weeks [146]. For steroid-refractory cases, other immunosuppressive agents (e.g., mycophenolate mofetil or the tumor necrosis factor alpha antibody, infliximab) may be required to obtain control of the immune mediated toxicity [144, 145]. Patients developing moderate to severe imAEs may require integrated multidisciplinary care that should include specialists in gastroenterology, pulmonology, dermatology, neurology, ophthalmology, endocrinology, or rheumatology, depending on the type of toxicity $[153,155]$. In addition, imAE awareness should be raised among healthcare providers outside the oncology team, such as emergency room physicians and nurses, who might be involved in managing patients receiving immunotherapy. In a real-world study investigating ipilimumab in 129 patients with metastatic melanoma, $26 \%$ of patients required corticosteroids for the management of AEs, and $5.4 \%$ were administered infliximab in the refractory setting [158]. In a large expanded-access program of nivolumab in combination with ipilimumab, which included 732 North American patients with advanced melanoma, grade 3/4 treatmentrelated AEs (TRAEs) occurred in $50 \%$ of patients, and $32 \%$ of the patients discontinued treatment due to TRAEs [159]. These results point to a safety profile consistent with clinical trial data.

\section{Quality of Life Associated with ICBs}

Although clinical outcomes for patients with cancer are often measured in terms of survival and response, patient-reported outcomes and health-related quality of life (HRQoL) are also important considerations from a patient perspective. Treatment with nivolumab or pembrolizumab has been shown to improve or maintain HRQoL compared with standard chemotherapy or targeted agents. An analysis of HRQoL from 


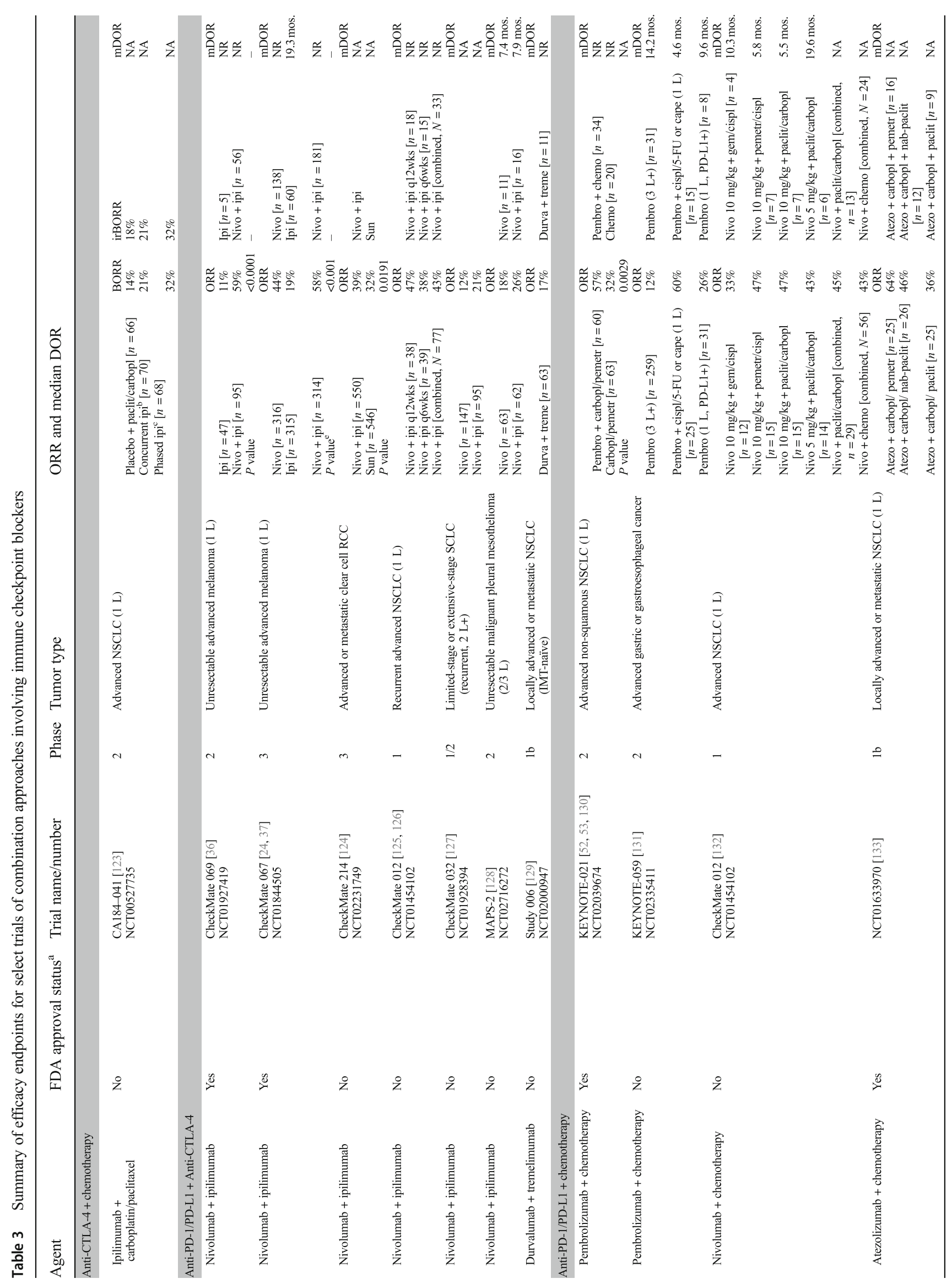




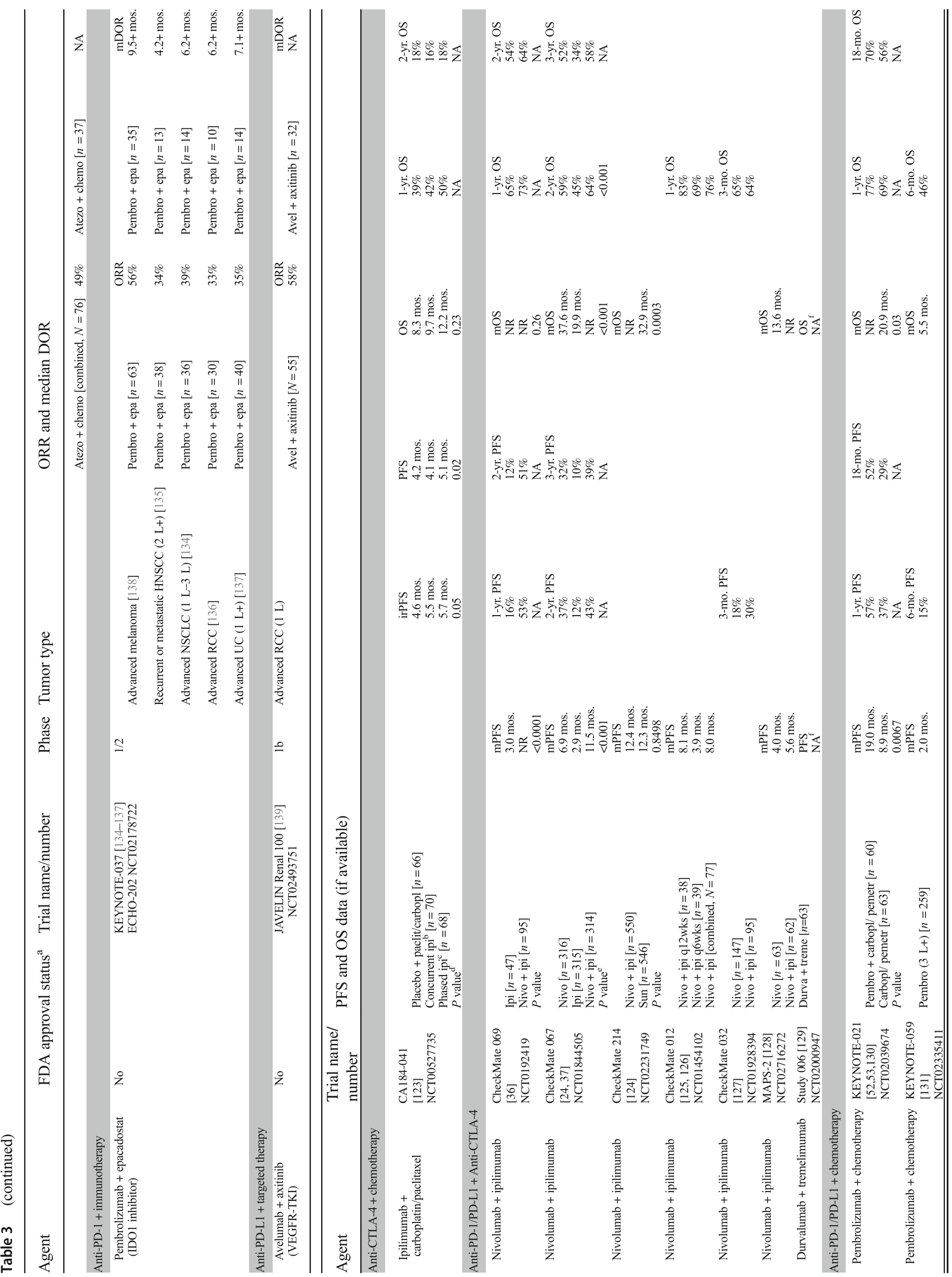




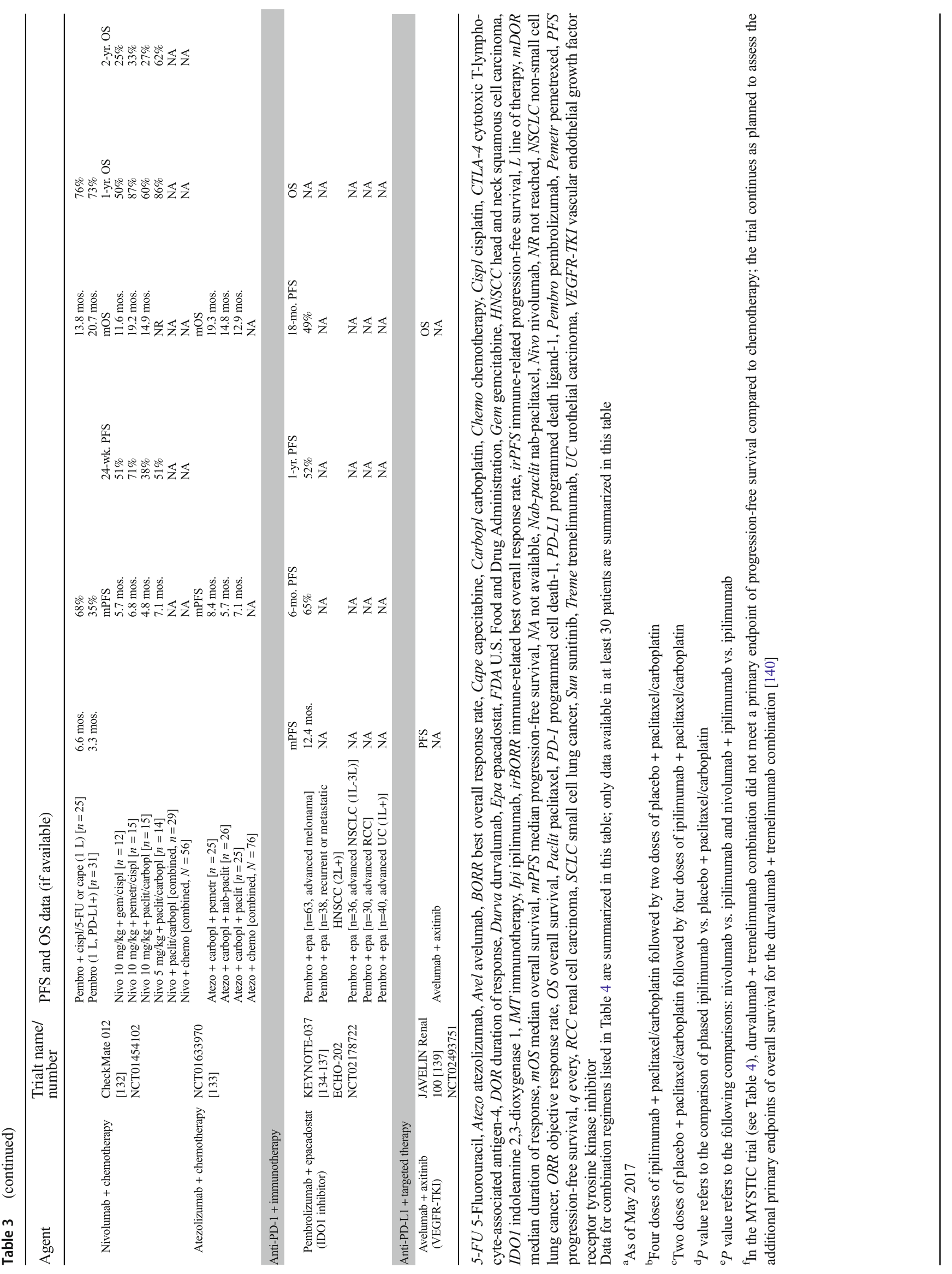


Table 4 Ongoing pharma-sponsored phase 3 trials of immunotherapy-based combination approaches for advanced malignancies

\begin{tabular}{|c|c|c|c|c|c|}
\hline Combination Regimen & Trial Design & Trial name/number & Tumor Type & Line & $\begin{array}{l}\text { Estimated Primary } \\
\text { Completion Date }\end{array}$ \\
\hline \multicolumn{6}{|c|}{ Ipilimumab-based combinations } \\
\hline \multirow{2}{*}{ Ipilimumab + chemotherapy } & $\begin{array}{l}\text { Ipilimumab + carboplatin/paclitaxel } \\
\text { vs. } \\
\text { Placebo + carboplatin/paclitaxel }\end{array}$ & $\begin{array}{l}\text { CA184-104 } \\
\text { NCT01285609 }\end{array}$ & $\begin{array}{l}\text { Stage IV or recurrent squamous } \\
\text { NSCLC }\end{array}$ & Any & $\begin{array}{l}\text { June } \\
2015\end{array}$ \\
\hline & $\begin{array}{l}\text { Ipilimumab + carboplatin/paclitaxel } \\
\text { vs. } \\
\text { Placebo + carboplatin/paclitaxel }\end{array}$ & $\begin{array}{l}\text { CA184-153 } \\
\text { NCT02279732 }\end{array}$ & $\begin{array}{l}\text { Stage IV or recurrent squamous } \\
\text { NSCLC }\end{array}$ & Any & $\begin{array}{l}\text { September } \\
2018\end{array}$ \\
\hline \multicolumn{6}{|c|}{ Nivolumab-based combinations } \\
\hline \multirow{3}{*}{ Nivolumab + ICB } & $\begin{array}{l}\text { Nivolumab + ipilimumab } \\
\text { vs. } \\
\text { Nivolumab } \\
\text { vs. } \\
\text { Bevacizumab }\end{array}$ & $\begin{array}{l}\text { CheckMate } 143 \\
\text { NCT02017717 }\end{array}$ & Grade 4 glioblastoma & $1 / 2 \mathrm{~L}$ & $\begin{array}{l}\text { January } \\
2017\end{array}$ \\
\hline & Nivolumab + ipilimumab & $\begin{array}{l}\text { CheckMate } 817 \\
\text { NCT02869789 }\end{array}$ & Stage IV or recurrent NSCLC & $1 \mathrm{~L}$ & $\begin{array}{c}\text { September } \\
2018\end{array}$ \\
\hline & $\begin{array}{l}\text { Nivolumab + ipilimumab } \\
\text { vs. } \\
\text { Nivolumab } \\
\text { vs. } \\
\text { Placebo }\end{array}$ & $\begin{array}{l}\text { CheckMate } 451 \\
\text { NCT02538666 }\end{array}$ & $\begin{array}{l}\text { Extensive-stage disease SCLC } \\
\text { with ongoing response of stable } \\
\text { disease or better following } \\
\text { platinum-based } 1 \mathrm{~L} \text { chemotherapy }\end{array}$ & $\begin{array}{l}\text { Consolidation } \\
\text { therapy }\end{array}$ & $\begin{array}{l}\text { September } \\
2018\end{array}$ \\
\hline $\begin{array}{l}\text { Nivolumab + ICB or } \\
\text { chemotherapy }\end{array}$ & $\begin{array}{l}\text { Nivolumab + ipilimumab } \\
\text { vs. } \\
\text { Nivolumab + platinum doublet chemotherapy } \\
\text { vs. } \\
\text { Nivolumab } \\
\text { vs. } \\
\text { Platinum doublet chemotherapy }\end{array}$ & $\begin{array}{l}\text { CheckMate } 227 \\
\text { NCT02477826 }\end{array}$ & Stage IV or recurrent NSCLC & $1 \mathrm{~L}$ & $\begin{array}{l}\text { January } \\
2018\end{array}$ \\
\hline $\begin{array}{l}\text { Nivolumab + immunomodulatory } \\
\text { therapy }\end{array}$ & $\begin{array}{l}\text { Nivolumab + pomalidomide + dexamethasone } \\
\text { vs. } \\
\text { Nivolumab + elotuzumab + pomalidomide + dexamethasone } \\
\text { vs. } \\
\text { Pomalidomide + dexamethasone }\end{array}$ & $\begin{array}{l}\text { CheckMate } 602 \\
\text { NCT02726581 }\end{array}$ & $\begin{array}{l}\text { Refractory or relapsed and } \\
\text { refractory multiple myeloma }\end{array}$ & $3 L^{+}$ & $\begin{array}{l}\text { November } \\
2018\end{array}$ \\
\hline \multicolumn{6}{|c|}{ Pembrolizumab-based combinations } \\
\hline \multirow[t]{2}{*}{ Pembrolizumab + chemotherapy } & $\begin{array}{l}\text { Pembrolizumab + carboplatin + paclitaxel or nab-paclitaxel } \\
\text { vs. } \\
\text { Placebo + carboplatin + paclitaxel or nab-paclitaxel }\end{array}$ & $\begin{array}{l}\text { KEYNOTE-407 } \\
\text { NCT02775435 }\end{array}$ & Stage IV squamous NSCLC & $1 \mathrm{~L}$ & $\begin{array}{c}\text { March } \\
2018\end{array}$ \\
\hline & $\begin{array}{l}\text { Neoadjuvant chemotherapy + pembrolizumab } \\
\text { vs. } \\
\text { Neoadjuvant chemotherapy + placebo } \\
\rightarrow \text { Surgery } \\
\text { Adjuvant pembolizumab vs adjuvant placebo }\end{array}$ & $\begin{array}{l}\text { KEYNOTE-522 } \\
\text { NCT03036488 }\end{array}$ & $\begin{array}{l}\text { Locally advanced non-metastatic } \\
\text { triple-negative breast cancer } \\
\text { (TNBC) }\end{array}$ & $\begin{array}{l}\text { Neoadjuvant/ } \\
\text { adjuvant }\end{array}$ & $\begin{array}{l}\text { November } \\
2018\end{array}$ \\
\hline $\begin{array}{l}\text { Pembrolizumab + investigational } \\
\text { ICB }\end{array}$ & $\begin{array}{l}\text { Pembrolizumab + epacadostat } \\
\text { vs. } \\
\text { Pembrolizumab + placebo }\end{array}$ & $\begin{array}{l}\text { KEYNOTE-252 } \\
\text { ECHO-301 } \\
\text { NCT02752074 }\end{array}$ & $\begin{array}{l}\text { Unresectable or metastatic } \\
\text { melanoma }\end{array}$ & $1 \mathrm{~L}$ & $\begin{array}{l}\text { May } \\
2018\end{array}$ \\
\hline $\begin{array}{l}\text { Pembrolizumab + } \\
\text { immunomodulatory therapy }\end{array}$ & $\begin{array}{l}\text { Pembrolizumab + pomalidomide + dexamethasone } \\
\text { vs. } \\
\text { Pomalidomide + dexamethasone }\end{array}$ & $\begin{array}{l}\text { KEYNOTE-183 } \\
\text { NCT02576977 }\end{array}$ & $\begin{array}{l}\text { Refractory or relapsed and } \\
\text { refractory multiple myeloma }\end{array}$ & $3 L+$ & $\begin{array}{l}\text { August } \\
2018\end{array}$ \\
\hline $\begin{array}{l}\text { Pembrolizumab + oncolytic viral } \\
\text { immunotherapy }\end{array}$ & $\begin{array}{l}\text { Pembrolizumab + T-VEC } \\
\text { vs. } \\
\text { Pembrolizumab + placebo }\end{array}$ & $\begin{array}{l}\text { KEYNOTE-034 } \\
\text { MASTERKEY-265 } \\
\text { NCT02263508 }\end{array}$ & $\begin{array}{l}\text { Unresectable stage IIIB-IVM1c } \\
\text { melanoma }\end{array}$ & $\begin{array}{l}\text { 1L (BRAF wt) } \\
2 \mathrm{~L}(\text { (BRAF } \\
\text { mut+) }\end{array}$ & $\begin{array}{l}\text { December } \\
2018\end{array}$ \\
\hline \multicolumn{6}{|c|}{ Atezolizumab-based combinations } \\
\hline $\begin{array}{l}\text { Atezolizumab }+ \text { chemotherapy }+ \\
\text { targeted therapy }\end{array}$ & $\begin{array}{l}\text { Atezolizumab + carboplatin/paclitaxel } \\
\text { vs. } \\
\text { Atezolizumab + carboplatin/paclitaxel + bevacizumab } \\
\text { vs. } \\
\text { Carboplatin/paclitaxel + bevacizumab }\end{array}$ & $\begin{array}{l}\text { IMpower } 150 \\
\text { NCT02366143 }\end{array}$ & Stage IV non-squamous NSCLC & $1 \mathrm{~L}$ & $\begin{array}{l}\text { November } \\
2017\end{array}$ \\
\hline \multirow{3}{*}{ Atezolizumab + chemotherapy } & $\begin{array}{l}\text { Atezolizumab + nab-paclitaxel/carboplatin } \\
\text { vs. } \\
\text { Nab-paclitaxel/carboplatin }\end{array}$ & $\begin{array}{l}\text { IMpower } 130 \\
\text { NCT02367781 }\end{array}$ & Stage IV non-squamous NSCLC & $1 \mathrm{~L}$ & $\begin{array}{l}\text { December } \\
2017\end{array}$ \\
\hline & $\begin{array}{l}\text { Atezolizumab + carboplatin/paclitaxel } \\
\text { vs. } \\
\text { Atezolizumab + carboplatin/nab-paclitaxel } \\
\text { vs. } \\
\text { Carboplatin/nab-paclitaxel }\end{array}$ & $\begin{array}{l}\text { IMpower } 131 \\
\text { NCT02367794 }\end{array}$ & Stage IV squamous NSCLC & $1 \mathrm{~L}$ & $\begin{array}{c}\text { January } \\
2018\end{array}$ \\
\hline & $\begin{array}{l}\text { Atezolizumab + gemcitabine + carboplatin/cisplatin } \\
\text { vs. } \\
\text { Placebo + gemcitabine + carboplatin/cisplatin } \\
\text { vs. } \\
\text { Atezolizumab }\end{array}$ & $\begin{array}{l}\text { IMvigor } 130 \\
\text { NCT02807636 }\end{array}$ & $\begin{array}{l}\text { Locally advanced or metastatic } \\
\text { UC }\end{array}$ & $1 \mathrm{~L}$ & $\begin{array}{l}\text { December } \\
2018\end{array}$ \\
\hline
\end{tabular}


Table 4 (continued)

\begin{tabular}{|c|c|c|c|c|c|}
\hline \multicolumn{6}{|l|}{ Avelumab-based combinations } \\
\hline Avelumab + chemotherapy & $\begin{array}{l}\text { Avelumab + PLD } \\
\text { vs. } \\
\text { Avelumab } \\
\text { vs. } \\
\text { PLD }\end{array}$ & $\begin{array}{l}\text { JAVELIN Ovarian } 200 \\
\text { NCT02580058 }\end{array}$ & $\begin{array}{l}\text { Platinum-resistantrefractory } \\
\text { ovarian cancer }\end{array}$ & 1-4L & $\begin{array}{l}\text { March } \\
2018\end{array}$ \\
\hline Avelumab + targeted therapy & $\begin{array}{l}\text { Avelumab + axitinib } \\
\text { vs. } \\
\text { Sunitinib }\end{array}$ & $\begin{array}{l}\text { JAVELIN Renal } 101 \\
\text { NCT02684006 }\end{array}$ & Advanced or metastatic RCC & 1L & $\begin{array}{l}\text { December } \\
2018\end{array}$ \\
\hline \multicolumn{6}{|c|}{ Durvalumab-based combinations } \\
\hline \multirow[t]{6}{*}{$\begin{array}{l}\text { Durvalumab + investigational } \\
\text { ICB }\end{array}$} & $\begin{array}{l}\text { Durvalumab + tremelimumab } \\
\text { vs. } \\
\text { Durvalumab } \\
\text { vs. } \\
\text { Paclitaxel/carboplatin or gemcitabine/cisplatin or } \\
\text { gemcitabine/carboplatin or pemetrexed/cisplatin or } \\
\text { pemetrexed/carboplatin }\end{array}$ & \begin{tabular}{|l|} 
MYSTIC \\
NCT02453282
\end{tabular} & Stage IV NSCLC & 1L & $\begin{array}{l}\text { June } \\
2017\end{array}$ \\
\hline & $\begin{array}{l}\text { Sub-study A (PD-L1+): } \\
\text { Durvalumab } \\
\text { vs. } \\
\text { Vinorelbine or gemcitabine or erlotinib } \\
\text { Sub-study B (PD-L1-): } \\
\text { Durvalumab + tremelimumab } \\
\text { vs. } \\
\text { Durvalumab } \\
\text { vs. } \\
\text { Tremelimumab } \\
\text { vs. } \\
\text { Vinorelbine or gemcitabine or erlotinib }\end{array}$ & $\begin{array}{l}\text { ARCTIC } \\
\text { NCT02352948 }\end{array}$ & NSCLC & $3 \mathrm{~L}$ & $\begin{array}{l}\text { November } \\
2017\end{array}$ \\
\hline & $\begin{array}{l}\text { Durvalumab + tremelimumab } \\
\text { vs. } \\
\text { Durvalumab } \\
\text { vs. } \\
\text { Cetuximab or docetaxel or paclitaxel or methotrexate or } \\
\text { 5-fluorouracil or capecitabine }\end{array}$ & $\begin{array}{l}\text { EAGLE } \\
\text { NCT02369874 }\end{array}$ & Recurrent or metastatic HNSCC & $2 \mathrm{~L}$ & $\begin{array}{c}\text { February } \\
2018\end{array}$ \\
\hline & $\begin{array}{l}\text { Durvalumab + tremelimumab } \\
\text { vs. } \\
\text { Durvalumab } \\
\text { vs. } \\
\text { Cetuximab + carboplatin or cisplatin + } 5 \text {-fluorouracil } \\
\end{array}$ & $\begin{array}{l}\text { KESTREL } \\
\text { NCT02551159 }\end{array}$ & Recurrent or metastatic HNSCC & 1L & $\begin{array}{l}\text { March } \\
2018\end{array}$ \\
\hline & $\begin{array}{l}\text { Durvalumab + tremelimumab } \\
\text { vs. } \\
\text { Durvalumab } \\
\text { vs. } \\
\text { Gemcitabine + carboplatin or cisplatin } \\
\end{array}$ & $\begin{array}{l}\text { DANUBE } \\
\text { NCT02516241 }\end{array}$ & Stage IV UC & 1L & $\begin{array}{l}\text { April } \\
2018\end{array}$ \\
\hline & $\begin{array}{l}\text { Durvalumab + tremelimumab } \\
\text { vs. } \\
\text { Paclitaxel/carboplatin or gemcitabine/cisplatin or } \\
\text { gemcitabine/carboplatin or pemetrexed/cisplatin or } \\
\text { pemetrexed/carboplatin }\end{array}$ & $\begin{array}{l}\text { NEPTUNE } \\
\text { NCT02542293 }\end{array}$ & Stage IV NSCLC & $1 \mathrm{~L}$ & $\begin{array}{l}\text { October } \\
2018\end{array}$ \\
\hline
\end{tabular}

$H N S C C$ head and neck squamous cell carcinoma, ICB immune checkpoint blocker, $L$ line of therapy, NSCLC non-small cell lung cancer, $P D-1$ programmed cell death-1, $P D-L 1$ programmed cell death ligand-1, $P L D$ pegylated liposomal doxorubicin, $R C C$ renal cell carcinoma, $S C L C$ small cell lung cancer, $T$-VEC talimogene laherparepvec, $U C$ urothelial carcinoma

This table includes phase 3 pharma-sponsored studies that expect to have primary results on or before Q4 2018 (based on clinicaltrials.gov) in tumor types different from those in which the combination regimens are already approved

${ }^{a}$ Durvalumab + tremelimumab combination did not meet a primary endpoint of progression-free survival compared to chemotherapy; the trial continues as planned to assess the additional primary endpoints of overall survival for the durvalumab + tremelimumab combination [140]

the phase 2 KEYNOTE-002 trial, which examined global health status and functional scales (quality of life and physical, emotional, cognitive, and social functioning) as well as symptom scales (fatigue, nausea, pain, dyspnea, insomnia, appetite loss, constipation, and diarrhea), showed that pembrolizumab improved or maintained HRQoL when compared with chemotherapy in patients with ipilimumabrefractory melanoma [160]. A recent analysis of HRQoL from the phase 3 KEYNOTE-045 study showed that pembrolizumab improved HRQoL when compared with chemotherapy in patients with platinum-refractory advanced UC
[161]. Several phase 3 studies comparing nivolumab with chemotherapy reported similar findings in treatment-naïve patients with melanoma (CheckMate 066) [162] and in patients with recurrent HNSCC (CheckMate 141) [31, 163]. Nivolumab was also associated with HRQoL improvement over the targeted agent, everolimus, in previously treated patients with advanced RCC (CheckMate 025) [164]. The phase 3 CheckMate 067 showed that ipilimumab/nivolumab combination therapy maintained HRQoL in treatment-naïve patients with melanoma; in this study, no clinically meaningful deterioration was observed in patients treated with 
ipilimumab/nivolumab combination therapy compared with those treated with ipilimumab [165]. Taken together, these findings indicating HRQoL improvement or maintenance with immunotherapy may support the preferred use of immunotherapies over some targeted agents, such as everolimus, or chemotherapy, especially from a patient perspective.

\section{Conclusions and Future Directions of Immunotherapy}

Immunotherapies are an emerging treatment for many cancer types, with distinct properties that distinguish these anticancer agents from traditional chemotherapy or targeted agents. Unlike chemotherapy or targeted agents, which generally act directly on the tumor cells, cancer immunotherapies generally function by modulating the immune system, thereby indirectly affecting tumor survival. Because of this, a unique pattern of responses has been reported with immunotherapies that includes pseudoprogression or mixed tumor responses, which can result in the perception of disease progression. In randomized controlled trials, ICBs have been consistently associated with durable responses and often increased rates of response compared with standards of care. Observations of improved or maintained HRQoL versus standard of care further add to the clinical benefits of ICB therapy. In addition, treatment with ICBs is associated with a distinct set of imAEs, which have the potential to be serious. Further studies are needed to evaluate the efficacy and safety of checkpoint blockade in special, difficult-to-treat populations, such as patients with preexisting immune-related conditions, low performance status, or brain metastases. ICBs are currently being studied in the neoadjuvant and adjuvant settings as well as in combination with novel investigational agents including other classes of immunotherapy and targeted agents. As the indications for ICBs expand and cancer treatment continues to shift towards a more personalized approach, the ability to identify patients who will derive the most benefit from immunotherapy will continue to evolve.

\section{Compliance with Ethical Standards}

Funding Medical writing support was provided by Stephanie K. Doerner, PhD, Francesca Balordi, PhD, and Robert Schupp, PharmD, CMPP, of The Lockwood Group (Stamford, CT, USA), in accordance with Good Publication Practice (GPP3) guidelines, and was funded by AstraZeneca (Wilmington, DE, USA).

Conflict of Interest Jeffrey Clarke has received grants from MedPacto, consulting fees from Inivata, and research support from Genentech, Bristol-Myers Squibb, and Adaptimmune Therapeutics. Daniel George has received research grant support from Acerta, AstraZeneca, and Millennium; consultancy fees from Acceleron Pharma and Merck; honoraria from BioPharm Communications/ClinTopics ${ }^{\circledR}$; research grant support and consultancy fees from Bristol-Myers Squibb, Exelixis,
Genentech, Novartis, and Janssen Pharmaceuticals; consultancy and speaker bureau fees from Dendreon Corporation/Valeant; consultancy fees and compensation for participating on steering committees from Myovant Sciences; research grant support, consultancy fees, and honoraria from Astellas/Medivation; research grant support, consultancy fees, and speaker bureau fees from Bayer Healthcare Pharmaceuticals and Sanofi-Aventis; research grant support, consultancy fees, and compensation for participating on steering committees from Pfizer and Viamet/ Innocrin. The Duke Institutional Conflict of Interest Committee has determined that Dr. George has no restrictions on any of his Duke University-related activities based upon payment received from any of the sponsors listed above. April Salama has received payment for participation on advisory boards for Bristol-Myers Squibb and Merck and for serving as a speaker for Bristol-Myers Squibb. Dr. Salama's research institution has received research grant support from Bristol-Myers Squibb, Celldex Therapeutics, Dynavax Technologies Corporation, Genentech, Immunocore, Merck, and Reata Pharmaceuticals. Stacey Lisi declares no conflict of interest.

Open Access This article is distributed under the terms of the Creative Commons Attribution-NonCommercial 4.0 International License (http:// creativecommons.org/licenses/by-nc/4.0/), which permits any noncommercial use, distribution, and reproduction in any medium, provided you give appropriate credit to the original author(s) and the source, provide a link to the Creative Commons license, and indicate if changes were made.

\section{References}

1. Dunn GP, Old LJ, Schreiber RD. The immunobiology of cancer immunosurveillance and immunoediting. Immunity. 2004;21(2): $137-48$.

2. Buchbinder EI, Desai A. CTLA-4 and PD-1 pathways: similarities, differences, and implications of their inhibition. Am J Clin Oncol. 2016;39(1):98-106.

3. Hanahan D, Weinberg RA. Hallmarks of cancer: the next generation. Cell. 2011;144(5):646-74.

4. TheraCys BCG. Live (Intravesical) [prescribing information]. Toronto: Sanofi Pasteur Ltd.

5. Proleukin [prescribing information]. Biberach/Riss, Germany: Boehringer Ingelheim Pharma.

6. SYLATRON. (peginterferon alfa-2b) [prescribing information]. Whitehouse Station: Merck \& Co., Inc.

7. PROVENGE. (sipuleucel-T) suspension for intravenous infusion [prescribing information]. Seattle: Dendreon Corporation.

8. IMLYGIC. (talimogene laherparepvec) suspension for intralesional injection [prescribing information]. Thousand Oaks: Amgen Inc.

9. KYMRIAH. (tisagenlecleucel) suspension for intravenous infusion [prescribing information]. East Hanover: Novartis Pharmaceuticals Corporation.

10. YESCARTA. (axicabtagene ciloleucel) suspension for intravenous infusion [prescribing information]. Santa Monica: Kite Pharma, Inc.

11. YERVOY. (ipilimumab) injection [prescribing information]. Princeton: Bristol-Myers Squibb.

12. OPDIVO. (nivolumab) injection [prescribing information]. Princeton: Bristol-Myers Squibb.

13. KEYTRUDA. (pembrolizumab) for injection [prescribing information]. Whitehouse Station: Merck \& Co., Inc.

14. TECENTRIQ. (atezolizumab) injection [prescribing information]. South San Francisco: Genentech, Inc. 
15. BAVENCIO. (avelumab) injection [prescribing information]. Rockland: EMD Serono, Inc.

16. IMFINZI. (durvalumab) injection, for intravenous use [prescribing information]. Wilmington: AstraZeneca Pharmaceuticals LP.

17. Hodi FS, O’Day SJ, McDermott DF, Weber RW, Sosman JA, Haanen JB, et al. Improved survival with ipilimumab in patients with metastatic melanoma. N Engl J Med. 2010;363(8):711-23.

18. Pappo AS, Bergeron C, Gore L, Sender LS, Dunkel IJ, Herzog $\mathrm{CE}$, et al. Phase II study of ipilimumab (IPI) in children and adolescents with unresectable stage III or IV malignant melanoma (MEL). J Clin Oncol. 2017;35(Suppl. 15) [abstract e21006]. https://doi.org/10.1200/JCO.2017.35.15_suppl.e21006.

19. Merchant MS, Wright M, Baird K, Wexler LH, RodriguezGalindo C, Bernstein D, et al. Phase I clinical trial of ipilimumab in pediatric patients with advanced solid tumors. Clin Cancer Res. 2016;22(6):1364-70.

20. Eggermont AM, Chiarion-Sileni V, Grob JJ, Dummer R, Wolchok JD, Schmidt H, et al. Adjuvant ipilimumab versus placebo after complete resection of high-risk stage III melanoma (EORTC 18071): a randomised, double-blind, phase 3 trial. Lancet Oncol. 2015;16(5):522-30.

21. Eggermont AM, Chiarion-Sileni V, Grob JJ, Dummer R, Wolchok JD, Schmidt H, et al. Prolonged survival in stage III melanoma with ipilimumab adjuvant therapy. N Engl J Med. 2016;375(19): 1845-55.

22. Weber JS, D'Angelo SP, Minor D, Hodi FS, Gutzmer R, Neyns B, et al. Nivolumab versus chemotherapy in patients with advanced melanoma who progressed after anti-CTLA-4 treatment (CheckMate 037): a randomised, controlled, open-label, phase 3 trial. Lancet Oncol. 2015;16(4):375-84.

23. Robert C, Long GV, Brady B, Dutriaux C, Maio M, Mortier L, et al. Nivolumab in previously untreated melanoma without BRAF mutation. N Engl J Med. 2015;372(4):320-30.

24. Larkin J, Chiarion-Sileni V, Gonzalez R, Grob JJ, Cowey CL, Lao $\mathrm{CD}$, et al. Combined nivolumab and ipilimumab or monotherapy in untreated melanoma. N Engl J Med. 2015;373(1):23-34.

25. Brahmer J, Reckamp KL, Baas P, Crinò L, Eberhardt WE, Poddubskaya E, et al. Nivolumab versus docetaxel in advanced squamous-cell non-small-cell lung cancer. N Engl J Med. 2015;373(2):123-35.

26. Felip Font E, Gettinger SN, Burgio MA, Antonia SJ, Holgado E, Spigel DR, et al. Three-year follow-up from CheckMate 017/057: nivolumab versus docetaxel in patients with previously treated advanced non-small cell lung cancer (NSCLC). Ann Oncol. 2017;28(Suppl. 5):v460-v496 [abstract 1301PD].

27. Borghaei H, Paz-Ares L, Horn L, Spigel DR, Steins M, Ready $\mathrm{NE}$, et al. Nivolumab versus docetaxel in advanced nonsquamous non-small-cell lung cancer. N Engl J Med. 2015;373(17):162739.

28. Motzer RJ, Escudier B, McDermott DF, George S, Hammers HJ, Srinivas S, et al. Nivolumab versus everolimus in advanced renalcell carcinoma. N Engl J Med. 2015;373(19):1803-13.

29. Escudier B, Motzer RJ, Sharma P, Wagstaff J, Plimack ER, Hammers HJ, et al. Treatment beyond progression in patients with advanced renal cell carcinoma treated with nivolumab in CheckMate 025. Eur Urol. 2017;72(3):368-76.

30. Younes A, Santoro A, Shipp M, Zinzani PL, Timmerman JM, Ansell S, et al. Nivolumab for classical Hodgkin's lymphoma after failure of both autologous stem-cell transplantation and brentuximab vedotin: a multicentre, multicohort, single-arm phase 2 trial. Lancet Oncol. 2016;17(9):1283-94.

31. Ferris RL, Blumenschein G Jr, Fayette J, Guigay J, Colevas AD, Licitra L, et al. Nivolumab for recurrent squamous-cell carcinoma of the head and neck. N Engl J Med. 2016;375(19):1856-67.

32. Sharma P, Retz M, Siefker-Radtke A, Baron A, Necchi A, Bedke $\mathrm{J}$, et al. Nivolumab in metastatic urothelial carcinoma after platinum therapy (CheckMate 275): a multicentre, single-arm, phase 2 trial. Lancet Oncol. 2017;18(3):312-22.

33. Overman MJ, McDermott R, Leach JL, Lonardi S, Lenz HJ, Morse MA, et al. Nivolumab in patients with metastatic DNA mismatch repair-deficient or microsatellite instability-high colorectal cancer (CheckMate 142): an open-label, multicentre, phase 2 study. Lancet Oncol. 2017;18(9):1182-91.

34. Crocenzi TS, El-Khoueiry AB, Yau TC, Melero I, Sangro B, Kudo M, et al. Nivolumab (nivo) in sorafenib (sor)-naive and experienced pts with advanced hepatocellular carcinoma (HCC): CheckMate 040 study. J Clin Oncol. 2017;35(Suppl. 15) [abstract 4013].

35. Postow MA, Chesney J, Pavlick AC, Robert C, Grossmann K, McDermott D, et al. Nivolumab and ipilimumab versus ipilimumab in untreated melanoma. N Engl J Med. 2015;372(21):2006-17.

36. Hodi FS, Chesney J, Pavlick AC, Robert C, Grossmann KF, McDermott DF, et al. Combined nivolumab and ipilimumab versus ipilimumab alone in patients with advanced melanoma: 2-year overall survival outcomes in a multicentre, randomised, controlled, phase 2 trial. Lancet Oncol. 2016;17(11):1558-68.

37. Wolchok JD, Chiorion-Sileni V, Gonzalez R, Rutkowski P, Grob JJ, Cowey CL, et al. Overall survival with combined nivolumab and ipilimumab in advanced melanoma. N Engl J Med. 2017;377(14):1345-56.

38. Robert C, Ribas A, Wolchok JD, Hodi FS, Hamid O, Kefford R, et al. Anti-programmed-death-receptor-1 treatment with pembrolizumab in ipilimumab-refractory advanced melanoma: a randomised dose-comparison cohort of a phase 1 trial. Lancet. 2014;384(9948):1109-17.

39. Ribas A, Puzanov I, Dummer R, Schadendorf D, Hamid O, Robert $\mathrm{C}$, et al. Pembrolizumab versus investigator-choice chemotherapy for ipilimumab-refractory melanoma (KEYNOTE002): a randomised, controlled, phase 2 trial. Lancet Oncol. 2015;16(8):908-18.

40. Robert C, Schachter J, Long GV, Arance A, Grob JJ, Mortier L, et al. Pembrolizumab versus ipilimumab in advanced melanoma. N Engl J Med. 2015;372(26):2521-32.

41. Garon EB, Rizvi NA, Hui R, Leighl N, Balmanoukian AS, Eder $\mathrm{JP}$, et al. Pembrolizumab for the treatment of non-small-cell lung cancer. N Engl J Med. 2015;372(21):2018-28.

42. Herbst RS, Baas P, Kim DW, Felip E, Pérez-Gracia JL, Han JY, et al. Pembrolizumab versus docetaxel for previously treated, PDL1-positive, advanced non-small-cell lung cancer (KEYNOTE010): a randomised controlled trial. Lancet. 2016;387(10027): 1540-50.

43. Reck M, Rodríguez-Abreu D, Robinson AG, Hui R, Csőszi T, Fülöp A, et al. Pembrolizumab versus chemotherapy for PD-L1positive non-small-cell lung cancer. N Engl J Med. 2016;375(19): 1823-33.

44. Chow LQ, Haddad R, Gupta S, Mahipal A, Mehra R, Tahara M, et al. Antitumor activity of pembrolizumab in biomarkerunselected patients with recurrent and/or metastatic head and neck squamous cell carcinoma: results from the phase Ib KEYNOTE012 expansion cohort. J Clin Oncol. 2016;34(32):3838-45.

45. Chen R, Zinzani PL, Fanale MA, Armand P, Johnson NA, Brice P, et al. Phase II study of the efficacy and safety of pembrolizumab for relapsed/refractory classic Hodgkin lymphoma. J Clin Oncol. 2017;35(19):2125-32.

46. Bellmunt J, de Wit R, Vaughn DJ, Fradet Y, Lee JL, Fong L, et al. Pembrolizumab as second-line therapy for advanced urothelial carcinoma. N Engl J Med. 2017;376(11):1015-26.

47. de Wit R, Vaughn DJ, Fradet Y, Lee J, Fong L, Vogelzang NJ, et al. Pembrolizumab (pembro) versus paclitaxel, docetaxel, or vinflunine for recurrent, advanced urothelial cancer (UC): mature 
results from the phase 3 KEYNOTE-045 trial. Ann Oncol. 2017;28(Suppl. 5):v605-v649 [abstract LBA37_PR].

48. Bajorin DF, De Wit R, Vaughn DJ, Fradet Y, Lee JL, Fong L, et al. Planned survival analysis from KEYNOTE-045: phase 3, openlabel study of pembrolizumab (pembro) versus paclitaxel, docetaxel, or vinflunine in recurrent, advanced urothelial cancer (UC). J Clin Oncol. 2017;35(Suppl. 15) [abstract 4501]. https://doi.org/ 10.1200/JCO.2017.35.15_suppl.4501.

49. Balar AV, Castellano D, O'Donnell PH, Grivas P, Vuky J, Powles $\mathrm{T}$, et al. First-line pembrolizumab in cisplatin-ineligible patients with locally advanced and unresectable or metastatic urothelial cancer (KEYNOTE-052): a multicentre, single-arm, phase 2 study. Lancet Oncol. 2017;18(11):1483-92.

50. Diaz L, Marabelle A, Kim TW, Geva R, Van Cutsem E, André T, et al. Efficacy of pembrolizumab in phase 2 KEYNOTE-164 and KEYNOTE-158 studies of microsatellite instability high cancers. Ann Oncol. 2017;28(Suppl. 5):v122-v141 [abstract 386P].

51. Fuchs CS, Doi T, Jang RWJ, Muro K, Satoh T, Machado M, et al. KEYNOTE-059 cohort 1: efficacy and safety of pembrolizumab (pembro) monotherapy in patients with previously treated advanced gastric cancer. J Clin Oncol. 2017;35(Suppl. 15) [abstract 4003]. https://doi.org/10.1200/JCO.2017.35.15_suppl.4003.

52. Langer CJ, Gadgeel SM, Borghaei H, Papadimitrakopoulou VA, Patnaik A, Powell SF, et al. Carboplatin and pemetrexed with or without pembrolizumab for advanced, non-squamous non-smallcell lung cancer: a randomised, phase 2 cohort of the open-label KEYNOTE-021 study. Lancet Oncol. 2016;17(11):1497-508.

53. Borghaei H, Langer CJ, Gadgeel S, Papadimitrakopoulou VA, Patnaik A, Powell SF, et al. Updated results from KEYNOTE021 cohort G: a randomized, phase 2 study of pemetrexed and carboplatin (PC) with or without pembrolizumab (pembro) as first-line therapy for advanced nonsquamous NSCLC. Ann Oncol. 2017;28(Suppl. 5):v605-v649 [abstract LBA49].

54. Rosenberg JE, Hoffman-Censits J, Powles T, van der Heijden MS, Balar AV, Necchi A, et al. Atezolizumab in patients with locally advanced and metastatic urothelial carcinoma who have progressed following treatment with platinum-based chemotherapy: a single-arm, multicentre, phase 2 trial. Lancet. 2016;387(10031):1909-20.

55. Powles T. IMvigor211: A phase III randomized study examining atezolizumab vs. chemotherapy for platinum-treated advanced urothelial carcinoma. Presented at: EACR-AACR-SIC 2017 Special Conference; June 24-27, 2017; Florence, Italy.

56. Balar AV, Galsky MD, Rosenberg JE, Powles T, Petrylak DP, Bellmunt J, et al. Atezolizumab as first-line treatment in cisplatin-ineligible patients with locally advanced and metastatic urothelial carcinoma: a single-arm, multicentre, phase 2 trial. Lancet. 2017;389(10064):67-76.

57. Rittmeyer A, Barlesi F, Waterkamp D, Park K, Ciardiello F, von Pawel J, et al. Atezolizumab versus docetaxel in patients with previously treated non-small-cell lung cancer (OAK): a phase 3, open-label, multicentre randomised controlled trial. Lancet. 2017;389(10066):255-65.

58. Fehrenbacher L, Spira A, Ballinger M, Kowanetz M, Vansteenkiste J, Mazieres J, et al. Atezolizumab versus docetaxel for patients with previously treated non-small-cell lung cancer (POPLAR): a multicentre, open-label, phase 2 randomised controlled trial. Lancet. 2016;387(10030):1837-46.

59. Kaufman HL, Russell J, Hamid O, Bhatia S, Terheyden P, D'Angelo SP, et al. Avelumab in patients with chemotherapyrefractory metastatic Merkel cell carcinoma: a multicentre, single-group, open-label, phase 2 trial. Lancet Oncol. 2016;17(10): 1374-85.

60. Apolo AB, Ellerton JA, Infante JR, Agrawal M, Gordon MS, Aljumaily R. Avelumab treatment of metastatic urothelial carcinoma (mUC) in the phase 1b JAVELIN solid tumor study: updated analysis with $\geq 6$ months of follow-up in all patients. Ann Oncol. 2017;28(Suppl. 5):v295-v329 [abstract 856P].

61. Apolo AB, Ellerton JA, Infante JR, Agrawal M, Gordon MS, Aljumaily R, et al. Updated efficacy and safety of avelumab in metastatic urothelial carcinoma (mUC): pooled analysis from 2 cohorts of the phase 1b Javelin solid tumor study. J Clin Oncol. 2017;35(Suppl. 15) [abstract 4528]. https://doi.org/10.1200/JCO. 2017.35.15 suppl.4528.

62. Powles T, O'Donnell PH, Massard C, Arkenau H-T, Friedlander TW, Holmes CJ, et al. Efficacy and safety of durvalumab in locally advanced or metastatic urothelial carcinoma updated results from a phase 1/2 open-label study. JAMA Oncol. 2017;14;3(9): e172411.

63. Kantoff PW, Higano CS, Shore ND, Berger ER, Small EJ, Penson DF, et al. Sipuleucel-T immunotherapy for castration-resistant prostate cancer. N Engl J Med. 2010;363(5):411-22.

64. Andtbacka RH, Kaufman HL, Collichio F, Amatruda T, Senzer N, Chesney J, et al. Talimogene laherparepvec improves durable response rate in patients with advanced melanoma. J Clin Oncol. 2015;33(25):2780-8.

65. Buechner J, Grupp SA, Maude SL, Boyer M, Bittencourt H, Laetsch TW, et al. Global registration trial of efficacy and safety of CTL019 in pediatric and young adult patients with relapsed/ refractory acute lymphoblastic leukemia: update to the interim analysis. Haematologica. 2017;102:178 [abstract S476].

66. Locke FL, Neelapu SS, Bartlett NL, Lekakis LJ, Miklos D, Jacobson CA, et al. Primary results from ZUMA-1: a pivotal trial of axicabtagene ciloleucel (axicel; KTE-C19) in patients with refractory aggressive non-Hodgkin lymphoma (NHL). Presented at: AACR Annual Meeting 2017; April 1-5, 2017; Washington, DC. [abstract CT019].

67. Cohen EE, Harrington KJ, Tourneau CL, Dinis J, Licitra L, Ahn $\mathrm{M}-\mathrm{J}$, et al. Pembrolizumab (pembro) vs standard of care (SOC) for recurrent or metastatic head and neck squamous cell carcinoma (R/M HNSCC): phase 3 KEYNOTE-040 trial. Ann Oncol. 2017;28(Suppl. 5):v605-v649 [abstract LBA45_PR].

68. Merck provides update on Phase 3 study of KEYTRUDA® (pembrolizumab) monotherapy in patients with previously treated recurrent or metastatic head and neck squamous cell carcinoma (HNSCC) [press release]. July 24, 2017.

69. Roche provides update on phase III study of TECENTRIQ® (atezolizumab) in people with previously treated advanced bladder cancer [Press Release]. May 10, 2017.

70. Antonia SJ, Villegas A, Daniel D, Vicente D, Murakami S, Hui R, et al. Durvalumab after chemoradiotherapy in stage III non-smallcell lung cancer. N Engl J Med. 2017;377(20):1919-29.

71. National Comprehensive Cancer Network. Clinical practice guidelines in oncology: non-small cell lung cancer. Version 2. 2018. https://www.nccn.org/professionals/physician_gls/pdf/ nscl.pdf. Accessed Dec 2017.

72. McKee AE, Farrell AT, Pazdur R, Woodcock J. The role of the U.S. Food and Drug Administration review process: clinical trial endpoints in oncology. Oncologist. 2010;15(Suppl 1):13-8.

73. Ribas A, Kefford R, Marshall MA, Punt CJ, Haanen JB, Marmol $\mathrm{M}$, et al. Phase III randomized clinical trial comparing tremelimumab with standard-of-care chemotherapy in patients with advanced melanoma. J Clin Oncol. 2013;31(5):616-22.

74. Brahmer JR, Rodriguez-Abreu D, Robinson AG, Rina Hui R, Csõszi T, Fülöp A, et al. Progression after the next line of therapy (PFS2) and updated OS among patients (pts) with advanced NSCLC and PD-L1 tumor proportion score (TPS) $\geq 50 \%$ enrolled in KEYNOTE-024. J Clin Oncol. 2017;35(Suppl. 15) [abstract 9000]. https://doi.org/10.1200/JCO.2017.35.15_suppl.9000.

75. Petrelli F, Coinu A, Cabiddu M, Borgonovo K, Ghilardi M, Lonati $\mathrm{V}$, et al. Early analysis of surrogate endpoints for metastatic 
melanoma in immune checkpoint inhibitor trials. Medicine (Baltimore). 2016;95(26):e3997.

76. Wilson MK, Karakasis K, Oza AM. Outcomes and endpoints in trials of cancer treatment: the past, present, and future. Lancet Oncol. 2015;16(1):e32-42.

77. Maio M, Grob JJ, Aamdal S, Bondarenko I, Robert C, Thomas L, et al. Five-year survival rates for treatment-naive patients with advanced melanoma who received ipilimumab plus dacarbazine in a phase III trial. J Clin Oncol. 2015;33(10):1191-6.

78. Schadendorf D, Hodi FS, Robert C, Weber JS, Margolin K, Hamid $\mathrm{O}$, et al. Pooled analysis of long-term survival data from phase II and phase III trials of ipilimumab in unresectable or metastatic melanoma. J Clin Oncol. 2015;33(17):1889-94.

79. Fiteni F, Westeel V, Pivot X, Borg C, Vernerey D, Bonnetain F. Endpoints in cancer clinical trials. J Visc Surg. 2014;151(1):1722.

80. BMS.com. Bristol-Myers Squibb receives approval from the U.S. Food and Drug Administration for the Opdivo (nivolumab) + Yervoy (ipilimumab) regimen in BRAF V600 wild-type unresectable or metastatic melanoma [press release]. October 1, 2015.

81. Flaherty KT, Hennig M, Lee SJ, Ascierto PA, Dummer R, Eggermont AM, et al. Surrogate endpoints for overall survival in metastatic melanoma: a meta-analysis of randomised controlled trials. Lancet Oncol. 2014;15(3):297-304.

82. Roach C, Zhang N, Corigliano E, Jansson M, Toland G, Ponto G, et al. Development of a companion diagnostic PD-L1 immunohistochemistry assay for pembrolizumab therapy in non-smallcell lung cancer. Appl Immunohistochem Mol Morphol. 2016;24(6):392-7.

83. Phillips T, Simmons P, Inzunza HD, Cogswell J, Novotny J Jr, Taylor C, et al. Development of an automated PD-L1 immunohistochemistry (IHC) assay for non-small cell lung cancer. Appl Immunohistochem Mol Morphol. 2015;23(8):541-9.

84. Ventana PD-L1 (SP142) Assay [package insert]. Tucson, AZ: Ventana Medical Systems, Inc.

85. Ventana PD-L1 (SP263) Assay [package Insert]. Tucson, AZ: Ventana Medical Systems, Inc.

86. Sholl LM, Aisner DL, Allen TC, Beasley MB, Borczuk AC, Cagle PT, et al. Programmed death ligand-1 immunohistochemistry - a new challenge for pathologists: a perspective from members of the pulmonary pathology society. Arch Pathol Lab Med. 2016;140(4):341-4.

87. Sacher AG, Gandhi L. Biomarkers for the clinical use of PD-1/ PD-L1 inhibitors in non-small-cell lung cancer: a review. JAMA Oncol. 2016;2(9):1217-22.

88. Gaule P, Smithy JW, Toki M, Rehman J, Patell-Socha F, Cougot $\mathrm{D}$, et al. A quantitative comparison of antibodies to programmed cell death 1 ligand 1. JAMA Oncol. 2016. https://doi.org/10.1001/ jamaoncol.2016.3015. [Epub ahead of print].

89. Hirsch FR, McElhinny A, Stanforth D, Ranger-Moore J, Jansson $\mathrm{M}$, Kulangara K, et al. PD-L1 immunohistochemistry assays for lung cancer: results from phase 1 of the blueprint PD-L1 IHC assay comparison project. J Thorac Oncol. 2017;12(2):208-22.

90. Ratcliffe MJ, Sharpe A, Midha A, Barker C, Scott M, Scorer P, et al. Agreement between programmed cell death ligand-1 diagnostic assays across multiple protein expression cutoffs in nonsmall cell lung cancer. Clin Cancer Res. 2017;23(14):3585-91.

91. Rimm DL, Han G, Taube JM, Yi ES, Bridge JA, Flieder DB, et al. A prospective, multi-institutional, pathologist-based assessment of 4 immunohistochemistry assays for PD-L1 expression in nonsmall cell lung cancer. JAMA Oncol. 2017;3(8):1051-8.

92. IRESSA. (gefitinib) tablets for oral use [prescribing information]. Wilmington: AstraZeneca Pharmaceuticals LP; 2015.

93. TARCEVA. (erlotinib) tablets, for oral use [prescribing information]. South San Francisco: Genentech, Inc.; 2016.
94. GILOTRIF. (afatinib) tablets, for oral use [prescribing information]. Ridgefield: Boehringer Ingelheim Pharmaceuticals, Inc.; 2016.

95. Gainor JF, Shaw AT, Sequist LV, Fu X, Azzoli CG, Piotrowska Z, et al. EGFR mutations and ALK rearrangements are associated with low response rates to PD-1 pathway blockade in non-small cell lung cancer: a retrospective analysis. Clin Cancer Res. 2016;22(18):4585-93.

96. Lee CK, Man J, Lord S, Links M, Gebski V, Mok T, et al. Checkpoint inhibitors in metastatic EGFR-mutated non-small cell lung cancer-a meta-analysis. J Thorac Oncol. 2017;12(2):4037.

97. Le DT, Durham JN, Smith KN, Wang H, Bartlett BR, Aulakh LK, et al. Mismatch repair deficiency predicts response of solid tumors to PD-1 blockade. Science. 2017;357(6349):409-13.

98. Le DT, Uram JN, Wang H, Bartlett BR, Kemberling H, Eyring $\mathrm{AD}$, et al. PD-1 blockade in tumors with mismatch-repair deficiency. N Engl J Med. 2015;372(26):2509-20.

99. Snyder A, Wolchok JD, Chan TA. Genetic basis for clinical response to CTLA-4 blockade in melanoma. N Engl J Med. 2014;371(23):2189-99.

100. Van Allen EM, Miao D, Schilling B, Shukla SA, Blank C, Zimmer L, et al. Genomic correlates of response to CTLA-4 blockade in metastatic melanoma. Science. 2015;350(6257): 207-11.

101. Rizvi NA, Hellmann MD, Snyder A, Kvistborg P, Makarov V, et al. Cancer immunology. Mutational landscape determines sensitivity to PD-1 blockade in non-small cell lung cancer. Science. 2015;348(6230):124-8.

102. Galsky MD, Saci A, Szabo PM, Azrilevich A, Horak C, Lambert A, et al. Impact of tumor mutation burden on nivolumab efficacy in second-line urothelial carcinoma patients: exploratory analysis of the phase II CheckMate 275 study. Ann Oncol. 2017;28(Suppl. 5):v295-v329 [abstract 848PD].

103. Ayers M, Lunceford J, Nebozhyn M, Murphy E, Loboda A, Kaufman DR, et al. IFN-gamma-related mRNA profile predicts clinical response to PD-1 blockade. J Clin Invest. 2017;127(8): 2930-40.

104. Bais C, Kuziora M, Morehouse C, Higgs BW, Raja R, Lee Y, et al. Biologic and clinical relevance of an IFNG mRNA signature (IFNGS) and PD-L1 protein expression in tumor and immune cells in urothelial cancer (UC) patients (pts) treated with durvalumab (D). J Clin Oncol. 2017;35(Suppl. 15) [abstract 3037]. https://doi.org/10.1200/JCO.2017.35.15_suppl.3037.

105. O’Donnell PH, Grivas P, Balar, AV, Bellmunt J, Vuky J, Powles T, et al. Biomarker findings and mature clinical results from KEYNOTE-052: first-line pembrolizumab (pembro) in cisplatinineligible advanced urothelial cancer (UC). J Clin Oncol. 2017;35(Suppl. 15) [abstract 4502]. https://doi.org/10.1200/JCO. 2017.35.15_suppl.4502.

106. Higgs BW, Morehouse CA, Streicher K, Brohawn PZ, Steele K, Rebelatto $\mathrm{M}$, et al. A baseline IFNG gene expression signature correlates with clinical outcomes in durvalumab-treated advanced NSCLC cancer patients. Presented at: AACR Annual Meeting 2017; April 1-5, 2017; Washington, DC. [abstract 1773].

107. Johnson DB, Sullivan RJ, Ott PA, Carlino MS, Khushalani NI, Ye $\mathrm{F}$, et al. Ipilimumab therapy in patients with advanced melanoma and preexisting autoimmune disorders. JAMA Oncol. 2016;2(2): 234-40.

108. Menzies AM, Johnson DB, Ramanujam S, Atkinson VG, Wong ANM, Park JJ, et al. Anti-PD-1 therapy in patients with advanced melanoma and preexisting autoimmune disorders or major toxicity with ipilimumab. Ann Oncol. 2017;28(2):368-76.

109. Goldberg SB, Gettinger SN, Mahajan A, Chiang AC, Herbst RS, Sznol M, et al. Pembrolizumab for patients with melanoma or non-small-cell lung cancer and untreated brain metastases: early 
analysis of a non-randomised, open-label, phase 2 trial. Lancet Oncol. 2016;17(7):976-83.

110. Tawbi HA-H, Forsyth PAJ, Algazi AP, Hamid O, Hodi FS, Moschos SJ, et al. Efficacy and safety of nivolumab (NIVO) plus ipilimumab (IPI) in patients with melanoma (MEL) metastatic to the brain: results of the phase II study CheckMate 204. J Clin Oncol. 2017;35(Suppl. 15) [abstract 9507]. https://doi.org/10. 1200/JCO.2017.35.15 suppl.9507.

111. George S, Motzer RJ, Hammers HJ, Redman BG, Kuzel TM, Tykodi SS, et al. Safety and efficacy of nivolumab in patients with metastatic renal cell carcinoma treated beyond progression: a subgroup analysis of a randomized clinical trial. JAMA Oncol. 2016;2(9):1179-86.

112. Chiou VL, Burotto M. Pseudoprogression and immune-related response in solid tumors. J Clin Oncol. 2015;33(31):3541-3.

113. Wolchok JD, Hoos A, O’Day S, Weber JS, Hamid O, Lebbé C, et al. Guidelines for the evaluation of immune therapy activity in solid tumors: immune-related response criteria. Clin Cancer Res. 2009;15(23):7412-20.

114. Danlos FX, Pagès C, Baroudjian B, Vercellino L, Battistella M, Mimoun M, et al. Nivolumab-induced sarcoid-like granulomatous reaction in a patient with advanced melanoma. Chest. 2016;149(5):e133-6.

115. Hodi FS, Hwu WJ, Kefford R, Weber JS, Daud A, Hamid O, et al. Evaluation of immune-related response criteria and RECIST v1.1 in patients with advanced melanoma treated with pembrolizumab. J Clin Oncol. 2016;34(13):1510-7.

116. Seiwert TY, Burtness B, Mehra R, Weiss J, Berger R, Eder JP, et al. Safety and clinical activity of pembrolizumab for treatment of recurrent or metastatic squamous cell carcinoma of the head and neck (KEYNOTE-012): an open-label, multicentre, phase 1b trial. Lancet Oncol. 2016;17(7):956-65.

117. Eisenhauer EA, Therasse P, Bogaerts J, Sargent D, Ford R, Dancey J, et al. New response evaluation criteria in solid tumours: revised RECIST guideline (version 1.1). Eur J Cancer. 2009;45(2):228-47.

118. Haddad R, Blumenschein Jr G, Fayette J, Guigay J, Colevas AD, Licitra L, et al. Treatment beyond progression with nivolumab in patients with recurrent or metastatic $(\mathrm{R} / \mathrm{M})$ squamous cell carcinoma of the head and neck (SCCHN) in the phase 3 checkmate 141 study: a biomarker analysis and updated clinical outcomes. Ann Oncol. 2017;28(Suppl. 5):v372-v394 [abstract 1043O].

119. Motzer RJ, Rini BI, McDermott DF, Redman BG, Kuzel TM, Harrison MR, et al. Nivolumab for metastatic renal cell carcinoma: results of a randomized phase II trial. J Clin Oncol. 2015;33(13):1430-7.

120. Necchi A, Joseph RW, Loriot Y, Hoffman-Censits J, Perez-Gracia JL, Petrylak DP, et al. Atezolizumab in platinum-treated locally advanced or metastatic urothelial carcinoma: post-progression outcomes from the phase II IMvigor210 study. Ann Oncol. 2017;28(12):3044-50.

121. Topalian SL, Hodi FS, Brahmer JR, Gettinger SN, Smith DC, McDermott DF, et al. Safety, activity, and immune correlates of anti-PD-1 antibody in cancer. N Engl J Med. 2012;366(26):244354.

122. Robert C, Long V, Schacter J, Arance A, Grob JJ, Mortier L, et al. Long-term outcomes in patients (pts) with ipilimumab (ipi)-naive advanced melanoma in the phase 3 KEYNOTE-006 study who completed pembrolizumab (pembro) treatment. J Clin Oncol. 2017;35(Suppl. 15) [abstract 9504]. https://doi.org/10.1200/JCO. 2017.35.15_suppl.9504.

123. Lynch TJ, Bondarenko I, Luft A, Serwatowski P, Barlesi F, Chacko R, et al. Ipilimumab in combination with paclitaxel and carboplatin as first-line treatment in stage IIIB/IV non-small-cell lung cancer: results from a randomized, double-blind, multicenter phase II study. J Clin Oncol. 2012;30(17):2046-54.
124. Escudier B, Tannir N, McDermott DF, Frontera OA, Melichar B, Plimack ER, et al. CheckMate 214: Efficacy and safety of nivolumab + ipilimumab $(\mathrm{N}+\mathrm{I}) \mathrm{v}$ sunitinib $(\mathrm{S})$ for treatmentnaïve advanced or metastatic renal cell carcinoma (mRCC), including IMDC risk and PD-L1 expression subgroups. Ann Oncol. 2017;28(Suppl. 5):v605-v649 [abstract LBA5].

125. Hellmann MD, Rizvi NA, Goldman JW, Gettinger SN, Borghaei $\mathrm{H}$, Brahmer JR, et al. Nivolumab plus ipilimumab as first-line treatment for advanced non-small-cell lung cancer (CheckMate 012): results of an open-label, phase 1, multicohort study. Lancet Oncol. 2017;18(1):31-41.

126. Goldman JW, Antonia SJ, Scott N, Gettinger SN, Borghaei H, Brahmer JR, et al. Nivolumab (N) plus ipilimumab (I) as firstline (1L) treatment for advanced (adv) NSCLC: 2 -yr OS and longterm outcomes from CheckMate 012. J Clin Oncol. 2017;35(Suppl. 15) [abstract 9093]. https://doi.org/10.1200/JCO. 2017.35.15 suppl.9093.

127. Hellmann MD, Ott PA, Zugazagoitia J, Ready NE, Hann CL, De Braud FG, et al. Nivolumab (nivo) \pm ipilimumab (ipi) in advanced small-cell lung cancer (SCLC): first report of a randomized expansion cohort from CheckMate 032. J Clin Oncol. 2017;35(Suppl. 15) [abstract 8503]. https://doi.org/10.1200/JCO. 2017.35.15_suppl.8503.

128. Zalcman G, Mazieres J, Greillier L, Lantuejoul S, Dò P, Bylicki O, et al. Second or 3rd line nivolumab (Nivo) versus nivo plus ipilimumab (Ipi) in malignant pleural mesothelioma (MPM) patients: updated results of the IFCT-1501 MAPS2 randomized phase 2 trial. Ann Oncol. 2017;28(Suppl. 5):v605-v649 [abstract LBA58_PR].

129. Antonia S, Goldberg SB, Balmanoukian A, Chaft JE, Sanborn RE, Gupta A, et al. Safety and antitumour activity of durvalumab plus tremelimumab in non-small cell lung cancer: a multicentre, phase 1b study. Lancet Oncol. 2016;17(3):299-308.

130. Papadimitrakopoulou V, Gadgeel SM, Borghaei H, Gandhi L, Patnaik A, Powell SF, et al. First-line carboplatin and pemetrexed (CP) with or without pembrolizumab (pembro) for advanced nonsquamous NSCLC: updated results of KEYNOTE-021 cohort G. J Clin Oncol. 2017;35(Suppl. 15) [abstract 9094]. https://doi. org/10.1200/JCO.2017.35.15_suppl.9094.

131. Wainberg ZA, Jalal S, Muro K, Yoon HH, Garrido M, Golan T, et al. KEYNOTE-059 update: efficacy and safety of pembrolizumab alone or in combination with chemotherapy in patients with advanced gastric or gastroesophageal (G/GEJ) cancer. Ann Oncol. 2017;28(Suppl. 5):v605-v649 [abstract LBA28_PR].

132. Rizvi NA, Hellmann MD, Brahmer JR, Juergens RA, Borghaei H, Gettinger S, et al. Nivolumab in combination with platinum-based doublet chemotherapy for first-line treatment of advanced nonsmall-cell lung cancer. J Clin Oncol. 2016;34(25):2969-79.

133. Liu SV, Camidge DR, Gettinger SN, Giaccone G, Heist RS, Hodi FS, et al. Atezolizumab (atezo) plus platinum-based chemotherapy (chemo) in non-small cell lung cancer (NSCLC): update from a phase Ib study. J Clin Oncol. 2017;35(Suppl. 15) [abstract 9092]. https://doi.org/10.1200/JCO.2017.35.15_suppl.9092.

134. Gangadhar TC, Schneider BJ, Bauer TM, Wasser JS, Spira AI, Patel SP, et al. Efficacy and safety of epacadostat plus pembrolizumab treatment of NSCLC: preliminary phase I/II results of ECHO-202/KEYNOTE-037. J Clin Oncol. 2017;35(Suppl. 15) [abstract 9014]. https://doi.org/10.1200/JCO. 2017.35.15_supp1.9014.

135. Hamid O, Bauer TM, Spira AI, Olszanski AJ, Patel SP, Wasser JS, et al. Epacadostat plus pembrolizumab in patients with SCCHN: preliminary phase I/II results from ECHO-202/KEYNOTE-037. J Clin Oncol. 2017;35(Suppl. 15) [abstract 6010]. https://doi.org/ 10.1200/JCO.2017.35.15_suppl.6010. 
136. Lara P, Bauer TM, Hamid O, Smith DC, Gajewski T, Gangadhar TC, et al. Epacadostat plus pembrolizumab in patients with advanced RCC: preliminary phase I/II results from ECHO-202/ KEYNOTE-037. J Clin Oncol. 2017;35(Suppl. 15) [abstract 4515]. https://doi.org/10.1200/JCO.2017.35.15 suppl.4515.

137. Smith DC, Gajewski T, Hamid O, Wasser JS, Olszanski AJ, Patel SP, et al. Epacadostat plus pembrolizumab in patients with advanced urothelial carcinoma: preliminary phase I/II results of ECHO-202/KEYNOTE-037. J Clin Oncol. 2017;35(Suppl. 15) [abstract 4503]. https://doi.org/10.1200/JCO.2017.35.15_suppl. 4503.

138. Hamid O, Gajewski TF, Frankel AE, Bauer TM, Olszanski AJ, Luke JJ, et al. Epacadostat plus pembrolizumab in patients with advanced melanoma: phase 1 and 2 efficacy and safety results from ECHO-202/KEYNOTE-037. Ann Oncol. 2017;28(Suppl. 5):v428-v448 [abstract 1214O].

139. Choueiri TK, Larkin JMG, Oya M, Thistlethwaite FC, Martignoni M, Nathan PD, et al. First-line avelumab + axitinib therapy in patients (pts) with advanced renal cell carcinoma (aRCC): results from a phase Ib trial. J Clin Oncol. 2017;35(Suppl. 15) [abstract 4504]. https://doi.org/10.1200/JCO.2017.35.15 suppl.4504.

140. AstraZeneca.com. AstraZeneca reports initial results from the ongoing MYSTIC trial in Stage IV lung cancer [press release]. July 27, 2017.

141. Curran MA, Montalvo W, Yagita H, Allison JP. PD-1 and CTLA4 combination blockade expands infiltrating $\mathrm{T}$ cells and reduces regulatory $\mathrm{T}$ and myeloid cells within B16 melanoma tumors. Proc Natl Acad Sci U S A. 2010;107(9):4275-80.

142. Long GV, Atkinson V, Cebon JS, Jameson MB, Fitzharris BM, McNeil CM, et al. Standard-dose pembrolizumab in combination with reduced-dose ipilimumab for patients with advanced melanoma (KEYNOTE-029): an open-label, phase 1b trial. Lancet Oncol. 2017;18(9):1202-10.

143. Planchard D, Yokoi T, McCleod MJ, Fischer JR, Kim YC, Ballas $\mathrm{M}$, et al. A phase III study of durvalumab (MEDI4736) with or without tremelimumab for previously treated patients with advanced NSCLC: rationale and protocol design of the ARCTIC study. Clin Lung Cancer. 2016;17(3):232-36.e1.

144. Weber JS, Kahler KC, Hauschild A. Management of immunerelated adverse events and kinetics of response with ipilimumab. J Clin Oncol. 2012;30(21):2691-7.

145. Weber JS, Postow M, Lao CD, Schadendorf D. Management of adverse events following treatment with anti-programmed death-1 agents. Oncologist. 2016;21(10):1230-40.

146. Michot JM, Bigenwald C, Champiat S, Collins M, Carbonnel F, Postel-Vinay S, et al. Immune-related adverse events with immune checkpoint blockade: a comprehensive review. Eur J Cancer. 2016;54:139-48.

147. Robert C, Ribas A, Hamid O, Daud A, Wolchok JD, Joshua AM, et al. Three-year overall survival for patients with advanced melanoma treated with pembrolizumab in KEYNOTE-001. J Clin Oncol. 2016; 34(Suppl. 15) [abstract 9503]. https://doi.org/10. 1200/JCO.2016.34.15_suppl.9503.

148. Topalian SL, Sznol M, McDermott DF, Kluger HM, Carvajal RD, Sharfman WH, et al. Survival, durable tumor remission, and longterm safety in patients with advanced melanoma receiving nivolumab. J Clin Oncol. 2014;32(10):1020-30.

149. Weber JS, Hodi FS, Wolchok JD, Topalian SL, Schadendorf D, Larkin J, et al. Safety profile of nivolumab monotherapy: a pooled analysis of patients with advanced melanoma. J Clin Oncol. 2017;35(7):785-92.

150. Petrylak DP, Powles T, Bellmunt J, Braiteh FS, Loriot Y, Morales $\mathrm{R}$, et al. Atezolizumab (atezo) in patients with metastatic urothelial carcinoma (mUC): a 2-year clinical update from a phase Ia study. J
Clin Oncol. 2017;35(Suppl. 6) [abstract 290]. https://doi.org/10. 1200/JCO.2017.35.6 suppl.290.

151. Friedman CF, Proverbs-Singh TA, Postow MA. Treatment of the immune-related adverse effects of immune checkpoint inhibitors: a review. JAMA Oncol. 2016;2(10):1346-53.

152. Haanen JBAG, Carbonnel F, Robert C, Kerr CK, Peters S, Larkin $\mathrm{J}$, et al. Management of toxicities from immunotherapy: ESMO clinical practice guidelines for diagnosis, treatment and follow-up. Ann Oncol. 2017;28(Suppl 4):iv119-42.

153. Bristol-Myers Squibb. YERVOY (ipilimumab): Immunemediated adverse reactions management guide. Princeton: Bristol-Myers Squibb; 2013.

154. Genentech, Inc. TECENTRIQ (atezolizumab) injection: managing select TECENTRIQ immune-related adverse events. South San Francisco: Genentech, Inc.; 2016.

155. Bristol-Myers Squibb. OPDIVO (nivolumab): immune-mediated adverse reactions management guide. Princeton: Bristol Myers Squibb; 2017.

156. Merck \& Co, Inc. KEYTRUDA (pembrolizumab) for injection: a guide to monitoring patients during treatment with KEYTRUDA. Whitehouse Station: Merck \& Co, Inc.; 2017.

157. AstraZeneca Pharmaceuticals. IMFINZI (durvalumab): immunemediated adverse reactions management handbook. Wilmington: AstraZeneca Pharmaceuticals LP; 2017.

158. Khoja L, Atenafu EG, Ye Q, Gedye C, Chappell M, Hogg D, et al. Real-world efficacy, toxicity and clinical management of ipilimumab treatment in metastatic melanoma. Oncol Lett. 2016;11(2):1581-5.

159. Hogg D, Chapman PB, Sznol M, Lao CD, Gonzalez R, Daniels GA, et al. Overall survival (OS) analysis from an expanded access program (EAP) of nivolumab (NIVO) in combination with ipilimumab (IPI) in patients with advanced melanoma (MEL). J Clin Oncol. 2017;35(Suppl. 15) [abstract 9522]. https://doi.org/ 10.1200/JCO.2017.35.15_suppl.9522.

160. Schadendorf D, Dummer R, Hauschild A, Robert C, Hamid O, Daud A, et al. Health-related quality of life in the randomised KEYNOTE-002 study of pembrolizumab versus chemotherapy in patients with ipilimumab-refractory melanoma. Eur J Cancer. 2016;67:46-54.

161. De Wit R, Bajorin DF, Bellmunt J, Fradet Y, Lee JL, Fong L, et al. Health-related quality of life (HRQoL) of pembrolizumab (pembro) vs chemotherapy (chemo) for previously treated advanced urothelial cancer (UC) in KEYNOTE-045. J Clin Oncol. 2017;35(Suppl. 15) [abstract 4530]. https://doi.org/10.1200/JCO. 2017.35.15_suppl.4530.

162. Long GV, Atkinson V, Ascierto PA, Robert C, Hassel JC, Rutkowski P, et al. Effect of nivolumab on health-related quality of life in patients with treatment-naive advanced melanoma: results from the phase III CheckMate 066 study. Ann Oncol. 2016;27(10):1940-6.

163. Harrington KJ, Ferris RL, Blumenschein G Jr, Colevas AD, Fayette J, Licitra L, et al. Nivolumab versus standard, singleagent therapy of investigator's choice in recurrent or metastatic squamous cell carcinoma of the head and neck (CheckMate 141): health-related quality-of-life results from a randomised, phase 3 trial. Lancet Oncol. 2017;18(8):1104-15.

164. Cella D, Grünwald V, Nathan P, Doan J, Dastani H, Taylor F, et al. Quality of life in patients with advanced renal cell carcinoma given nivolumab versus everolimus in CheckMate 025: a randomised, open-label, phase 3 trial. Lancet Oncol. 2016;17(7): 994-1003.

165. Schadendorf D, Larkin J, Wolchok J, Hodi FS, Chiarion-Sileni V, Gonzalez R, et al. Health-related quality of life results from the phase III CheckMate 067 study. Eur J Cancer. 2017;82:80-91. 